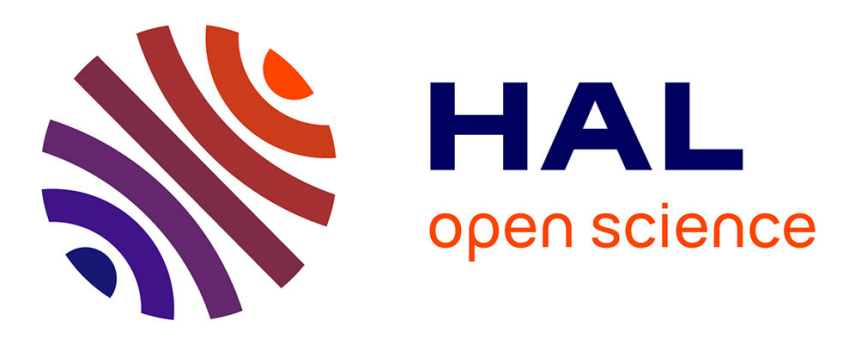

\title{
Bicyclic 5-6 Systems With One Bridgehead (Ring Junction) Nitrogen Atom: Two Extra Heteroatoms 0:2
}

Claudia Lalli

\section{To cite this version:}

Claudia Lalli. Bicyclic 5-6 Systems With One Bridgehead (Ring Junction) Nitrogen Atom: Two Extra Heteroatoms 0:2. Comprehensive Heterocyclic Chemistry IV, Elsevier, pp.659-684, 2022, 10.1016/b978-0-12-409547-2.14939-x . hal-03481501

\section{HAL Id: hal-03481501 https://hal-univ-rennes1.archives-ouvertes.fr/hal-03481501}

Submitted on 4 Jan 2022

HAL is a multi-disciplinary open access archive for the deposit and dissemination of scientific research documents, whether they are published or not. The documents may come from teaching and research institutions in France or abroad, or from public or private research centers.
L'archive ouverte pluridisciplinaire HAL, est destinée au dépôt et à la diffusion de documents scientifiques de niveau recherche, publiés ou non, émanant des établissements d'enseignement et de recherche français ou étrangers, des laboratoires publics ou privés. 


\section{Comprehensive Heterocyclic Chemistry IV}

Bicyclic 5-6 Systems with One Bridgehead (Ring Junction) Nitrogen Atom: Two Extra Heteroatoms 0:2

Author and Co-author Contact Information

Claudia LALLI

Univ Rennes, CNRS, ISCR UMR 6226, F-35000 Rennes, France

claudia.lalli@univ-rennes1.fr

+33223233106

1 INTRODUCTION

2 THEORETICAL METHODS

3 EXPERIMENTAL STRUCTURAL METHODS

3.1 X-Ray Studies

3.2 NMR Studies

3.3 Mass Spectrometry Studies

4 THERMODINAMIC ASPECTS

5 REACTIVITY OF FULLY CONJUGATED RINGS

5.1 Electrophilic Attack at Carbon

5.2 Nucleophilic Attack at Carbon

5.3 Other reactions

6 REACTIVITY OF NONCONJUGATED RINGS

6.1 Nucleophilic attack at Carbon

6.2 Electrophilic attack at Nitrogen

7 REACTIVITY OF SUBSTITUENTS ATTACHED TO RING CARBON ATOMS

8 RING SYNTHESES CLASSIFIED BY NUMBER OF RING ATOMS IN EACH COMPONENT
8.1 Pyrrolo[1,2-b][1,2,4]triazine
8.2 Pyrrolo[1,2-c][1,2,3]triazine
8.3 Pyrrolo[2,1-f][1,2,4]triazine
8.4 Pyrrolo[1,2-c][1,2,4]triazine
8.5 Pyrrolo[1,2-a][1,3,5]triazine
8.6 Pyrrolo[1,2-d][1,2,4]triazine

9 RING SYNTHESIS BY TRANSFORMATION OF ANOTHER RING

10 IMPORTANT COMPOUNDS AND APPLICATIONS 


\section{INTRODUCTION}

This chapter reviews bicyclic systems containing five- and six- fused rings with one ring junction nitrogen atom and two extra heteroatoms in the six-membered ring. The heteroatoms are mainly nitrogen, but a number of oxygen, sulfur, boron and phosphorus have also been described in the literature. This chapter is an update of the previous related book chapters, [1] [2] therefore will be concentrated on the literature appeared starting from 2008. No other general review on this topic exists, however the history and the use in medicinal chemistry of the pyrrolo[2,1-f][1,2,4]triazine core has been recently treated in a digest, [3] and their pharmacological activities, structural modifications and structure-activity relationship (SAR) have been reported [4] with a particular attention on their action over fibroblast growth factor receptors (FGFRs). [5] Moreover $[1,2,4]$ triazines condensed with five-membered heterocycles or with bicyclic systems and their use as anticancer compounds have been overviewed. [6]

Among the plethora of ring system fitting within the criteria of this chapter, the most studied are undoubtedly the regioisomeric pyrrolotriazines (1-6), both fully conjugated and nonconjugated, and related benzo derivatives (Figure 1). The other known systems are listed with references provided and include: pyrrolo-fused 1,2,4-benzothiadiazines 7a-c, which structures were assigned by COSY, $\mathrm{HMBC}$ and HSQC NMR analysis, IR and mass measurement, and unambiguously confirmed by single crystal X-ray analysis; [7] chiral 2,3,3a,4-tetrahydro- $1 \mathrm{H}$-pyrrolo[2,1-c][1,2,4]benzothiadiazine 5,5dioxides $\mathbf{8 a}$ (S18986) and $\mathbf{8 b}$, that make the object of on-column stopped-flow multidimensional HPLC studies for the determination of hydrolysis and enantiomerization rate constants; [8] [9] [10] the achiral $\mathbf{8} \mathbf{b}$ was also synthesized by thermal cyclization under solvent free conditions, starting from chloroacylaminobenzenesulfonamides; $[11](R)$ and $(S)$ enantiomers of 7-chloro-9-(furan-3-yl)2,3,3a,4-tetrahydro-1H-benzo[e]pyrrolo[2,1-c][1,2,4]thiadiazine 5,5-dioxide $8 \mathrm{c}$ was synthesized for its pharmacological activity and chemical stability; [12] chiral 2,3,5,6-tetrahydro$[1,2,4]$ thiadiazino[6,5,4-hi]indole 1,1-dioxides $9 \mathbf{a}-\mathbf{b}$, of which the reactivity behaviour towards $\mathrm{NaBH}_{3} \mathrm{CN}$ was studied; [13] 3-vinylhexahydro-2H-pyrrolo[1,2-b][1,2,6]thiadiazine 1,1-dioxide 10 , that was synthesized via intramolecular amination catalysed by $\mathrm{Co}(\mathrm{II})$-based metalloradical catalyst from the corresponding $\mathrm{N}$-allylic sulfamoyl azide and which structure was unambiguously confirmed by single crystal X-ray analysis; [14] trans-2H-pyrrolo[1,2-b][1,2,6]thiadiazine 1,1-dioxide 11 were prepared by $\mathrm{Pd}$-catalysed carboamination reaction of 2-allyl and 2,5-diallyl pyrrolidinyl sulfamides via a stereoselective anti-aminopalladation pathway; [15] a library of 160 members of isoindolinethiadiazinanes 12, obtained via a sequence including a domino Heck-aza-Michael sequence, followed by cyclization with paraformaldehyde or 1,1'-carbonyldiimidazole (CDI), [16] sequence optimized by a combination of microwave heating and continuous-flow organic synthesis; [17] 2,3,3a,4tetrahydro-1H-pyrrolo[1',2':4,5][1,3,4]oxadiazino[2,3-a]isoindol-10(5aH)-ones 13a-g which structure was unambiguously confirmed by single crystal X-ray analysis; [18] diethyl-7-methyldihydro- $4 \mathrm{H}$ pyrrolo[2,1-d][1,3,5]dioxazine-6,6(7H)-dicarboxylate 14 was accidentally synthesized as single diastereomer from diethylaminomalonate, crotonaldehyde and formaldehyde under secondary amine catalysis; [19] oxadiazine salt $\mathbf{1 5}$ was synthesized by a two step procedure involving a Co(II)[20] or $\mathrm{Ni}(\mathrm{II})$ - [21] catalysed cross coupling of 2-benzamidopyridine 1-oxide with terminal alkyne, followed by oxidation; bicyclic and tricyclic aza-peroxides 16 and 17 were obtained via a photooxygenation key step; [22] meso-1,3,5-oxadiazines 18 were obtained by electrochemical decarboxylative oxidation of $\mathrm{N}$-acyl-aminoacids; [23] pyrrolo[2,1-d][1,2,5]oxadiazines 19 were synthesized by (3+3)-cycloaddition of $N$-vinylpyrroles and nitrones; [24] psycotripine 20 , an alkaloid isolated from Psychotria pilifera leaves, which structure was confirmed by mono and bidimensional 
NMR experiments, high resolution ESI MS and by comparison of calculated and experimental ECD; [25] the enantioselective total synthesis of (-)-terengganensine A $\mathbf{2 1}$ was accomplished by a key Noyori's catalytic enantioselective transfer hydrogenation[26] and a formal total synthesis involving a photoredox catalytic nitrogen-centered radical cascade reaction has also been reported. [27] Heterocycles containing phosphorus as heteroatom such as $1 H$-pyrrolo[1,2c][1,3,2] oxazaphosphorines 22 have also been described. [28] Manganese (III) complexes 23 have been described as potent orally active peroxynitrite scavengers. [29] Systems containing a boron atom, of general formula $\mathbf{2 4}$ are having great success, if we judge by the number of publications that has literally exploded in the last 10 years. Indeed, about one hundred articles and patents can be counted in the 2008-2018 period covered by this chapter. The most described systems are BODIPYs and derivatives, which are widely used in different fields of application: in materials science as dyes and fluorescent organic pigments, [30] in catalysis, [31] in analytical chemistry such as fluorescent probes, [32] and in biology as labelling molecules to probe protein-protein interactions. [33] Finally heterocycles of general formula $\mathbf{2 5}$ have also been synthesized. [34]

Since no systematic studies of experimental structural as well as theoretical methods exist for those compounds, a little space is devoted to this topic. The synthesis and the chemical reactivity of pyrrolotriazines (1-6) will be deeply described instead. 


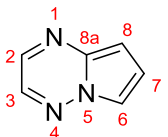

Pyrrolo[1,2-b][1,2,4]triazine

1

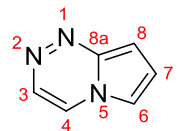

Pyrrolo[1,2-c][1,2,4]triazine

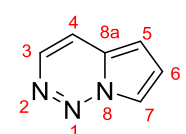

Pyrrolo[1,2-c][1,2,3]triazine

2<smiles>c1cc2ncncn2c1</smiles>

Pyrrolo[1,2-a][1,3,5]triazin

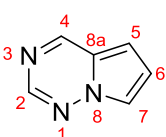

Pyrrolo[2,1-f][1,2,4]triazine

3<smiles>c1cc2cnncn2c1</smiles>

4<smiles>[R]C1CN2C([R])(C1)Nc1ccccc1S2(=O)=O</smiles>

7a $\mathrm{R}=\mathrm{Me}, \mathrm{R}^{1}=\mathrm{H}$ 7b $\mathrm{R}=\mathrm{R}^{1}=\mathrm{Me}$ 7c $\mathrm{R}=\mathrm{R}^{1}=\mathrm{H}$<smiles>[R]C[C@H]1C[C@@H](C[R])N(C[R])S(=O)(=O)N1[R16]</smiles>

11<smiles>[R]c1ccc2c(c1)S(=O)(=O)N[C@@H]1CCCN21</smiles>

8a $R=R^{1}=H S 18986$ 8b $\mathrm{R}=\mathrm{Cl} \mathrm{R}{ }^{1}=\mathrm{H}$ 8c $\mathrm{R}=\mathrm{Cl} \mathrm{R}^{1}=3$-furanyl<smiles>[R][X]c1cccc2c1C1CS(=O)(=O)N([R])C([X])N1C2</smiles>

$12 \mathrm{X}=\mathrm{H}$ or $\mathrm{O}$, 160-member library
5<smiles>C=C[C@@H]1C[C@@H]2CCCN2S(=O)(=O)N1</smiles>

10

9a $\mathrm{R}=\mathrm{H}, \mathrm{R}^{1}=\mathrm{H}$ 9b $\mathrm{R}=\mathrm{Cl}, \mathrm{R}^{1}=\mathrm{Me}$<smiles>[R]C12OC[C@@H]3CCCN3N1C(=O)c1ccccc12</smiles>

13a $\mathrm{R}=\mathrm{H} \quad$ 13d $\mathrm{R}=\mathrm{Pr}$ 13b $R=M e \quad 13$ e $R=$ allyl 13c $\mathrm{R}=\mathrm{Pr} \quad 13 \mathrm{f} \mathrm{R}=\mathrm{Bn}$ 13g R=p-OMe- $\mathrm{Ph}-\mathrm{CHOH}$<smiles>CCOC(=O)C1(C)[C@H](C)C[C@@H]2OCOCN21</smiles>

14<smiles>[R]C1C[C@H]2O[C@@H]3CC([R1])C(=O)N3C([R])N2C1=O</smiles><smiles>[R]c1cn2c(c1[R])C(C)ON([R])C2[R]</smiles>

19<smiles>C=C([Al])C1CN2C(=O)CCC2OOC1C(=C)[Te]</smiles>

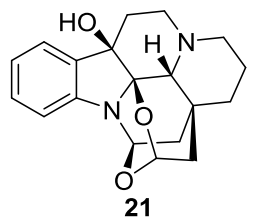

20<smiles>[R]CN1CCC[C@@]1(C)CC([R])OP[R]</smiles>

22
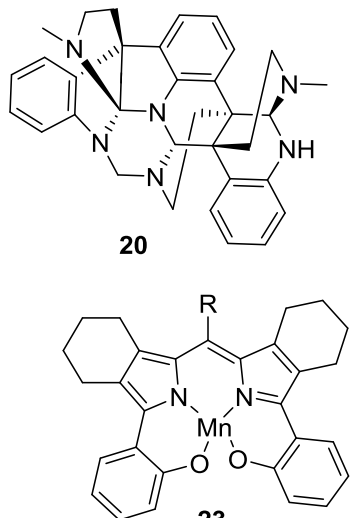

23

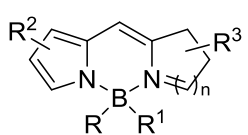

24

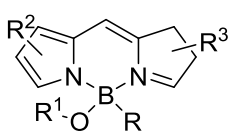

25

Figure 1.

\section{THEORETICAL METHODS}

Systematic studies, falling within the scope of this chapter, do not exist. The only two exceptions rely on the prediction of biological properties for drug discovery. Quantum mechanical calculations can be used to explain the inhibition provided by heteroaromatic rings containing nitrogen atoms towards Cytochrome P450s. [35] In particular the complexation energies of $\mathrm{Fe}$ (III) heme in its doublet and sextet state with a set of heteroaromatic rings has been calculated. For pyrrolo[1,2c] $[1,2,3]$ triazine (2) the $\Delta \mathrm{E}=2.2 \mathrm{kcal} / \mathrm{mol}$ for $\mathrm{Fe}(\mathrm{III})$ in doublet state and $\Delta \mathrm{E}=4.3 \mathrm{Kcal} / \mathrm{mol}$ in sextet 
state if $\mathrm{Fe}(\mathrm{III})$ is complexed on the nitrogen in the 2 position. If $\mathrm{Fe}(\mathrm{III})$ is linked to the nitrogen in position 3 the $\Delta \mathrm{E}=-2.1 \mathrm{kcal} / \mathrm{mol}$ for $\mathrm{Fe}(\mathrm{III})$ in doublet state and $\Delta \mathrm{E}=4.1 \mathrm{Kcal} / \mathrm{mol}$ in sextet state. These energies do not represent a risk of P450s inhibition since the barrier is below $\Delta E=-4.5$ $\mathrm{kcal} / \mathrm{mol}$ for $\mathrm{Fe}(\mathrm{III})$ in doublet state. The hydrogen-bond acceptor ability of pyrrolo[1,2c] $[1,2,3]$ triazine (2) has also been calculated using the Gaussian09 program. [36] To do so two quantum descriptors have been investigated, the $\Delta \mathrm{E}(\mathrm{H})$, which is the energy change of a hydrogen atom after complexation, relative to a $\mathrm{H}$-bond complex property; and the $V_{\min }$, that is the local minimum electrostatic potential value on the hydrogen-bond accepting sites, relative to a $\mathrm{H}$-bond acceptor site property. For pyrrolo[1,2-c][1,2,3]triazine (2) $\Delta \mathrm{E}(\mathrm{H})=70.1 \mathrm{~kJ} / \mathrm{mol}$, and $V_{\min }=-184.1$ $\mathrm{kJ} / \mathrm{mol}$ for the nitrogen in position 2; instead for the nitrogen in position $3 \Delta \mathrm{E}(\mathrm{H})=71.4 \mathrm{~kJ} / \mathrm{mol}$, and $V_{\min }=-225.5 \mathrm{~kJ} / \mathrm{mol}$, indicating that the nitrogen sites are effective $\mathrm{H}$-bond acceptor sites.

\section{EXPERIMENTAL STRUCTURAL METHODS}

\subsection{X-Ray Studies}

No systematic studies of this type have been undertaken. The structures of some compounds listed in Figure 2 have been confirmed by single crystal X-ray analysis. Heterodiquinanes containing triazine 26 [37] and 27 [38] have been isolated from the photochemical reaction of 7-methoxy-3-[1(methoxyimino) ethyl]- $N$-phenyl-1,2,diydrocinnoline 1,2-dicarboximide with diethyl 1,3acetonedicarboxylate. Their structure and stereochemistry were determined by X-ray diffraction. The structure and the relative stereochemistry of compound 28a were unambiguously confirmed by single crystal X-ray diffraction. [39] Compound 29 was synthesized as cis diastereomer (96:4) via a domino cyclohydrocarbonylation/addition sequence. [40] The ORTEP plot of molecule $\mathbf{3 0}$ is also represented [41], in the same manner the structure of compound $\mathbf{3 1}$ was determined by X-ray crystallographic analysis and the synthesis of this compound Is described in Scheme 28. [42] The absolute stereochemistry assignment of compound 32 [43] as well as the one of the $C$-nucleoside Hepatitis C virus inhibitors, GS-6620 33 and GS-5734 34, adenosine analogues, have been determined by $\mathrm{X}$-ray analysis. [44] [45]

A serie of molecules was co-crystallized with the enzyme active site and the crystal structures are reported (Figure 2). The one of compound $\mathbf{3 5}$ co-crystallized with the Met kinase domain was obtained in order to understand the binding mode of the pyrrolo triazine in the enzyme ATP binding site. [46] The key binding interactions have been pointed out: the N1 of the pyrrolotriazine core donates a $\mathrm{H}$ to the Met1160, the terminal $\mathrm{NH}_{2}$ on the piperidine ring creates an ionic interaction with the residue of Asp1164, the central fluorinated phenyl ring is involved in $\pi$ stacking interaction with Phe1223, and finally the acylurea carbonyl is implicated in a $\mathrm{H}$ bond with the backbone $\mathrm{NH}$ of Asp1222. X-ray structures of compounds 36a-e co-complexed with unphosphorylated p38 $\alpha$ were solved shielding light on the nature of the binding interactions between these molecules and the enzyme. Three key $\mathrm{H}$-bonds are identified in common for the four molecules: one between the C6amide carbonyl and the Met 109 residue, and two for the $5^{\prime}-R^{1}$ substitution, which is an hydroxamate or amide, between the carbonyl and the NH with the residues Asp168 and Glu71 respectively. For 36a-b [47] and BMS 582949 36e [48] Asp168 forms an extra H-bond with the N3 of the pyrrolotriazine, while for 36c [49] the pyrrolotriazine core interacts via the N1 with the Leu 171 residue. Finally, for 36d [50] an enhanced hydrophobic interaction due to the phenyl ring on the C6 ketone is thought to be responsible of an improved enzyme activity. An X-ray co-crystal structure of compounds 37a-c complexed with the IGF-1R kinase domain was solved revealing the hydrogen bond donor-acceptor-donor triad across the amino-pyrazole substituent to the Glu1050, Leu1051 
and Met1052 residues (Figure 2). [51] [52] Compounds 38, $\mathbf{3 9}$ and $\mathbf{4 0}$ have been co-crystallized as complex with MAP4K4. The three molecules fit the folded P-loop and create three hydrogen bonds with Glu106 and Cys108. Compound 16 and 25 bring a 4-pyridine which allows better interaction with Lys54, otherwise the phenyl group of 16 in the 6 position of the pyrrolotriazine as well as the pyrazole on the same position of compound 25 fit a partially hydrophobic pocket formed by the residues Phe107, Cys108 and Val31. [53]

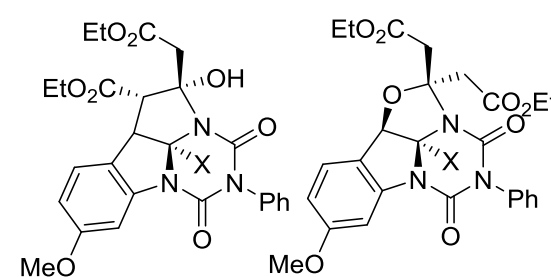

$26 \mathrm{X}=\mathrm{MeC}=\mathrm{NOMe}$<smiles>CCOC(=O)c1cc(-c2nn3cccc3c(=O)[nH]2)c(-c2ccccc2O)nc1N</smiles>

27<smiles>O=C1NC2c3ccccc3C=C(c3ccccc3)N2C1c1ccccc1</smiles>

31

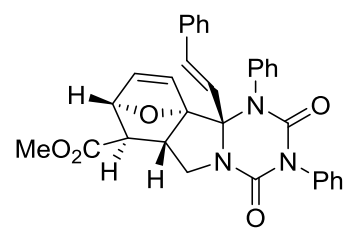

28a<smiles>CO[C@H]1CCCN2C(=O)N3CC(ONOCc4ccccc4)C[C@H]3C(=O)N12</smiles>

29<smiles>COc1cc(C2CCN(CCOC(=O)c3ccc(Br)cc3)CC2O)ccc1Nc1ncc2ccc(-c3ccccc3OC)n2n1</smiles>

32

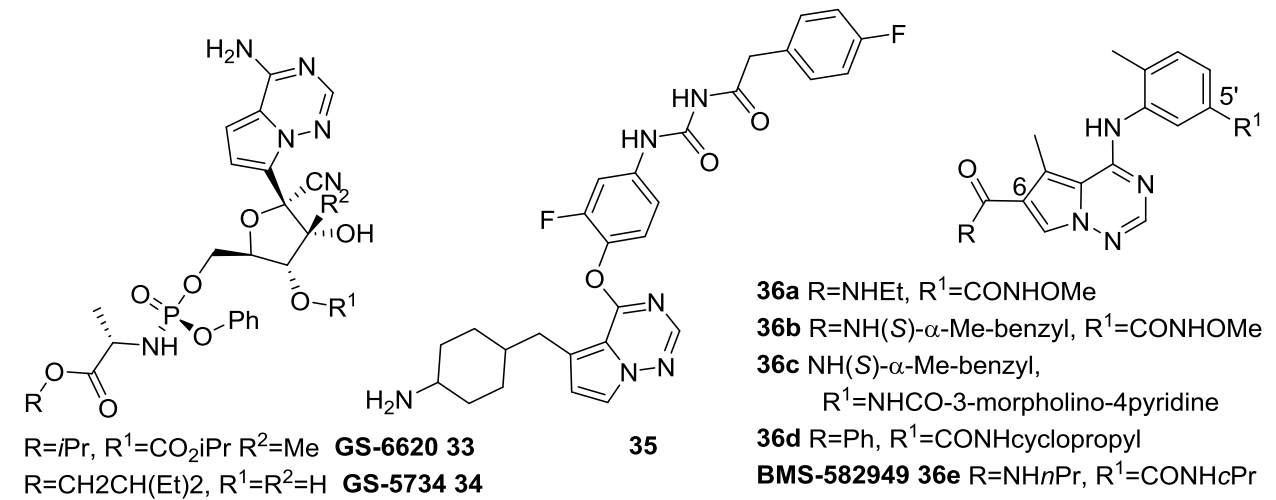

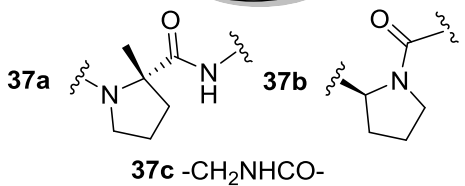

$37 \mathrm{c}-\mathrm{CH}_{2} \mathrm{NHCO}-$<smiles>c1cncc(Nc2ncnn3cccc23)c1</smiles>

38<smiles>[R]c1cc2c(Nc3ccncc3)ncnn2c1</smiles>

$39 \mathrm{R}=\mathrm{Ph}$

$40 \mathrm{R}=4$-pyrazolyl

Figure 2.

\subsection{NMR Studies}

The structure and the relative stereochemistry of compounds 28a-c were confirmed by NOESY (Figure 3).[39] Detailed assignements of the ${ }^{1} \mathrm{H}$ and ${ }^{13} \mathrm{C}$ signals of Nocarsine $\mathrm{A} 4 \mathbf{4 1}$, isolated from a soil sample collected in China, were unambiguously accomplished by NMR techniques including COSY, HSQC, ROESY and HMBC (Figure 3). [54] The NMR spectroscopic properties of several furo[2', $\left.3^{\prime}: 4,5\right]$ pyrrolo[1,2-d][1,2,4]triazin-ones $\mathbf{4 2}$ and -thiones $\mathbf{4 3}$ were investigated. In particular it was put in 
evidence the influence of various substituents on the triazine ring on ${ }^{1} \mathrm{H}$ - and ${ }^{13} \mathrm{C}-\mathrm{NMR}$ chemical shifts(Figure 3). [55]
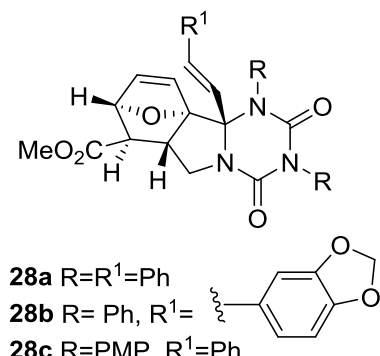

28c $\mathrm{R}=\mathrm{PMP}, \mathrm{R}^{1}=\mathrm{Ph}$

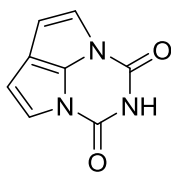

41

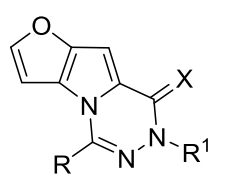

$42 \mathrm{X}=\mathrm{O} \quad \mathrm{R}=\mathrm{H}, \mathrm{CH}_{2} \mathrm{Cl}, \mathrm{CH}_{3}$

$43 \mathrm{X}=\mathrm{S} \quad \mathrm{R}_{1}=\mathrm{H}, \mathrm{CH}_{3}, \mathrm{n}-\mathrm{C}_{4} \mathrm{H}_{9}$ $\mathrm{CH}_{2} \mathrm{Ph}, \mathrm{CH}_{2} \mathrm{CO}_{2} \mathrm{CH}_{3}$

Figure 3.

\subsection{Mass Spectrometry Studies}

There have been no systematic studies on the use of mass spectroscopy in the serie of systems falling within this chapter.

\section{THERMODINAMIC ASPECTS}

No thermodynamic studies have been systematically undertaken for this class of compounds.

\section{REACTIVITY OF FULLY CONJUGATED RINGS}

The pyrrolo triazines can be described as a five-membered $\pi$-electron rich heterocycle fused with a six-membered $\pi$-electron poor one. For this reason, it can be considered that the expected reactivity of the pyrrole ring is towards electrophilic reagents while the nucleophilic agents react preferentially with the six-membered ring.

\subsection{Electrophilic Attack at Carbon}

As expected, the pyrrole ring undergoes electrophilic attack to the carbon atoms. Only one study has been reported on the electrophilic substitution reaction at C-9 atom on the tricyclic thieno[ $\left.2^{\prime}, 3^{\prime}: 4,5\right]$ pyrrolo[1,2-d][1,2,4]triazin-8(7H)-one 44 . Regioselective bromination of the pyrrole ring with excess of NBS in the presence of $\mathrm{K}_{2} \mathrm{CO}_{3}$ gave product 45 (Scheme 1). [56]<smiles>Cc1n[nH]c(=O)c2cc3sccc3n12</smiles>

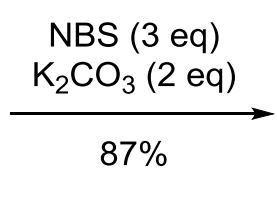<smiles>Cc1n[nH]c(=O)c2c(Br)c3sccc3n12</smiles>

Scheme 1

\subsection{Nucleophilic Attack at Carbon}

Due to the nature of the six-membered $\pi$-electron deficient triazine ring, these systems undergo nucleophilic attack at carbon atoms. The only example reported describes the nucleophilic substitution reaction of 8 -Cl-furo[ $\left[2^{\prime}, 3^{\prime}: 4,5\right]$ pyrrolo[1,2- $\left.d\right][1,2,4]$ triazine $\mathbf{4 6}$ with sodium ethoxide to deliver the ethoxy derivative $\mathbf{4 7}$ in $57 \%$ yield (Scheme 2). [57] 


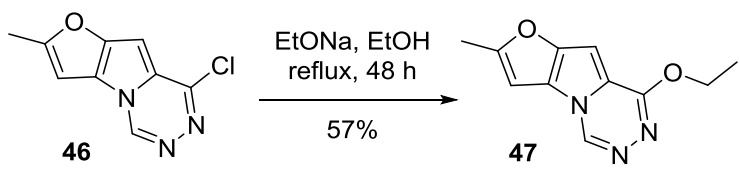

Scheme 2

\subsection{Other reactions}

Compound $\mathbf{4 4}$ undergoes Pd catalysed Suzuki coupling with different arylboronic acids to yield C-9 substituted compounds $\mathbf{4 8}$ (Scheme 3). The sequence bromination/Suzuki coupling was performed in one pot. [56]
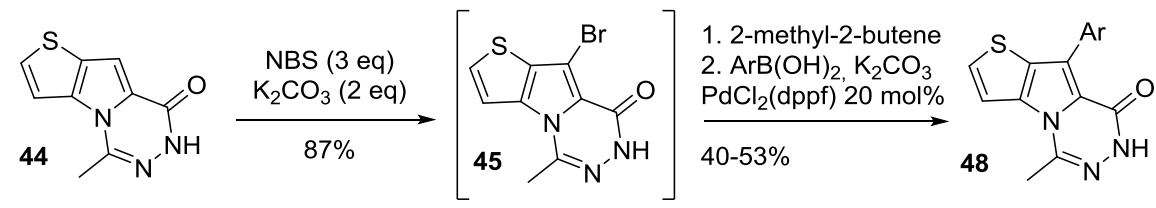

Scheme 3

Starting from intermediate $\mathbf{4 9}$ a library of substituted pyrrolo[2,1-f][1,2,4]triazines $\mathbf{5 1}$ has been synthesized. The Suzuki coupling on the C-7 position has been performed with ortho-substituted arylboronic acids in the presence of $\mathrm{Pd}(\mathrm{OAc})_{2}$ to give compounds $\mathbf{5 0}$ and then the oxidation of the sulphide to sulfoxide with $m$-CPBA followed by the coupling with the suited amine, under $\mathrm{MW}$ irradiation, delivered the desired compounds $\mathbf{5 1}$. These latter can be obtained as well reversing the two steps described above (Scheme 4). [58]

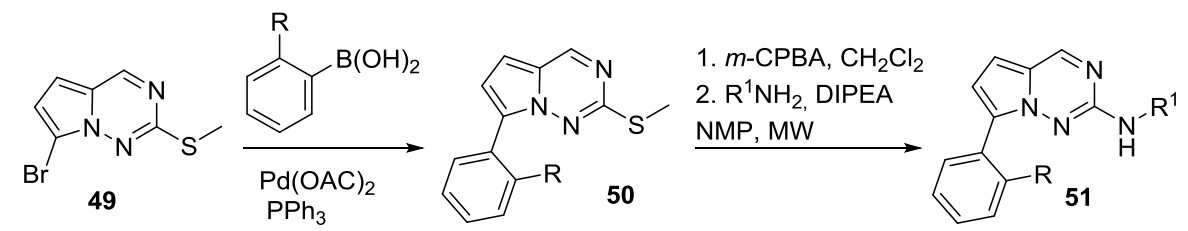

$\mathrm{R}=\mathrm{OMe}, \mathrm{CONH}_{2}, \mathrm{SO}_{2} \mathrm{Me}, \mathrm{NHSO}_{2} \mathrm{Me}, \mathrm{NMeSO}_{2} \mathrm{Me}$

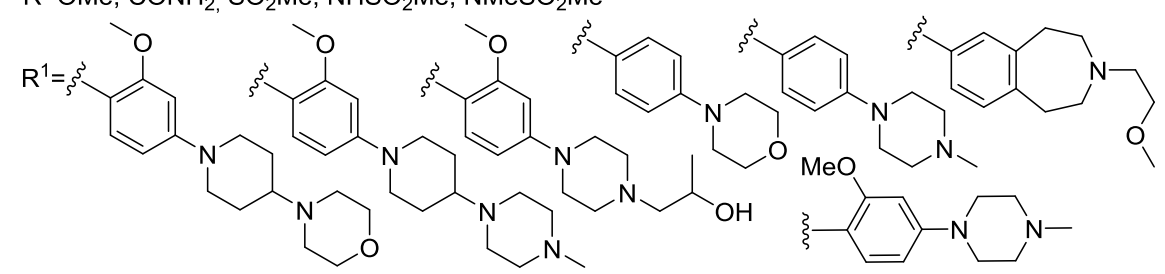

Scheme 4

2,4-dichloropyrrolo[2,1-f][1,2,4]triazine 52 underwent Pd-catalysed Suzuki then Buchwald coupling reactions on the position $\mathrm{C}-4$ and $\mathrm{C}-2$ respectively. Compound $\mathbf{5 2}$ was thus treated with 4trifluoromethoxyphenylboronic acid in the presence of $\mathrm{Pd}(\mathrm{PPh})_{3} \mathrm{Cl}_{2}$ to yield $\mathbf{5 3}$, followed by reaction with methyl 4-aminobenzoate in the presence of $\mathrm{Pd}(\mathrm{OAc})_{2}$ and BINAP under $\mathrm{MW}$ irradiation, to lead to compound 54 (Scheme 5). [59] 


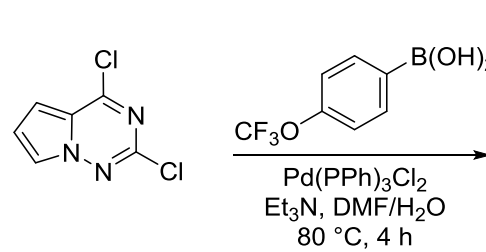

52

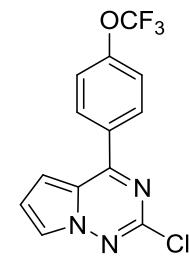

53

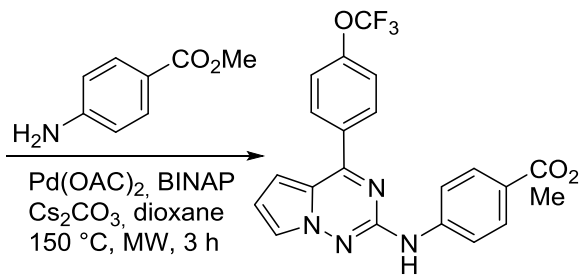

54

Scheme 5

The Suzuki coupling has been also used to functionalize the C-5 position of the pyrrolo[2,1$f][1,2,4]$ triazine skeleton, as an example see compound 35 figure 2 .

\section{REACTIVITY OF NONCONJUGATED RINGS}

Undoubtedly the most studied systems fitting within the criteria of this chapter are bicycles containing one or two oxo groups in the six-membered ring, and their equilibrium forms containing the corresponding hydroxyl group. The reactivity of the cycle can be compared to the one of cyclic amides, therefore they react with nucleophiles.

\subsection{Nucleophilic attack at Carbon}

The majority of references deal with the nucleophilic attack at the carbonyl group resulting in substitution rather than ring opening. Most of the reactions consist in the transformation of the pyrrolo[2,1-f][1,2,4]triazin-(one)s into the fully aromatic C-2 and/or C-4 chlorinated derivatives followed by nucleophilic substitution of the chloroimidates with alcohols or amines to deliver the corresponding ethers or amines. Substitution of the position C-2 has been treated for only two examples, depicted in scheme 6 . In the first case the hydroxyl group in C-2 position of compound 55 was transformed into the corresponding triflate before substitution with the appropriate aniline to give 56 (eq a). [43] [60] In the second example both position C-2 and C-4 of compound 52 were modified by displacement of $\mathrm{Cl}$ before on position C-4, with 5-cyclopropyl-3-aminopyrazole, to deliver $\mathbf{5 7}$ and then on C-2 with a (S)-proline derivatives to lead to compounds $\mathbf{5 8}$ (eq. b). [51]

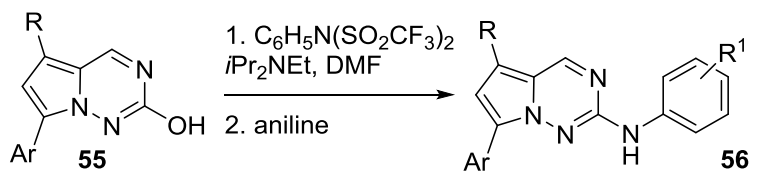

eq. a

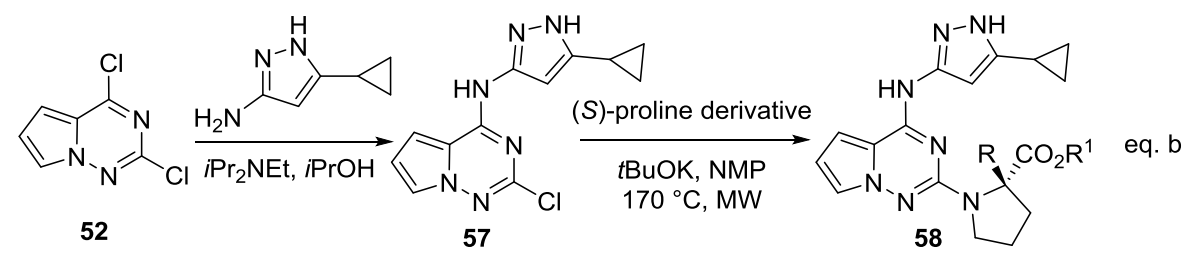

Scheme 6

Most of the examples deal with the substitution of the C-4 position, by transformation of the pyrrolo[2,1-f][1,2,4]triazinone 59 into the heteroaryl chloride 60 upon treatment with $\mathrm{POCl}_{3}$, then reaction with different amines such as 5-cyclopropyl-3-aminopyrazole [51] [52], $m$-anisidines [46] [47] [48] [49] [50] [61], morpholine [62], 1-(3-fluorobenzyl)-1H-indazol-5-amine [63] and finally 4aminopyridine [53] to give the corresponding amines 61-65. The substitution of 60 with 2-fluoro-4- 
nitrophenol [46] or with 2-fluoro-4-aminophenol derivatives [64] can alternatively lead to the corresponding ethers 66-67 (Scheme 7).<smiles>[R]c1nn2c([R])c([R])c([R])c2c(=O)[nH]1</smiles>

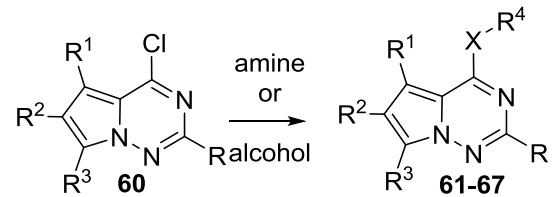<smiles></smiles><smiles></smiles>

Scheme 7

Treatment of pyrrolo[2,1-f][1,2,4]triazinone 68 with $\mathrm{POCl}_{3}$, followed by reduction with $\mathrm{NaBH}_{4}$ and reoxidation with DDQ gave the aromatic triazine 69 (Scheme 8). [65]

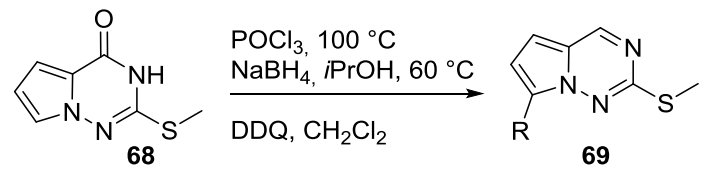

Scheme 8.

Thionation of thieno[2',3':4,5]pyrrolo[1,2- $d][1,2,4]$ triazin-8(7H)-ones 70 in the presence of Lawesson's reagent followed by $S$-alkylation with 2 -bromo- $N$-substituted acetamides gave compounds $72[66]$ while thionation of furo[2',3':4,5]pyrrolo[1,2- $d][1,2,4]$ triazin-8(7H)-ones 71 with $\mathrm{P}_{2} \mathrm{~S}_{5}$ yielded compounds 73 [67] (Scheme 9).

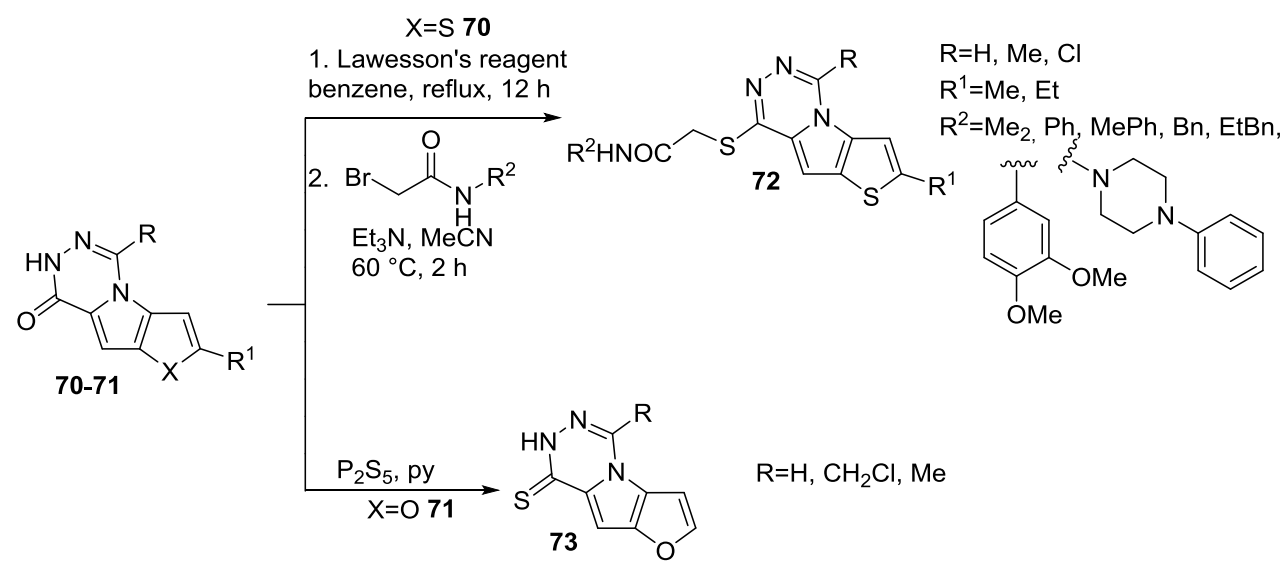

Scheme 9 


\subsection{Electrophilic attack at Nitrogen}

Direct $N$-alkylation of cyclic amide nitrogen of thieno or furo[ $\left[2^{\prime}, 3^{\prime}: 4,5\right]$ pyrrolo[1,2-d][1,2,4]triazin8(7H)-ones 71 and 72 with 2-bromo- $N$-substituted acetamides [66] or with alkyl halides [67] respectively, lead to compounds $\mathbf{7 4}$ and $\mathbf{7 5}$ (Scheme 10)

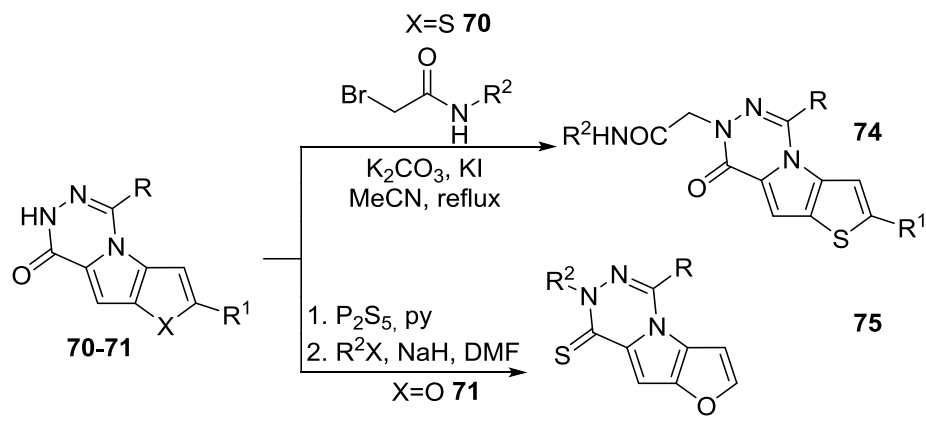

Scheme 10

\section{REACTIVITY OF SUBSTITUENTS ATTACHED TO RING CARBON ATOMS}

Several functional groups have been introduced on the different positions of the pyrrolotriazine core. The substitution of position C-2 and C-7 of the pyrrolo[2,1-f][1,2,4]triazine 76 has been explored by conversion of the cyano group, before into carboxylic acid, and then into amides, to give 77, while the thioether was before oxidized to sulfone and then replaced with amines to deliver compounds 78 (Scheme 11). [68]

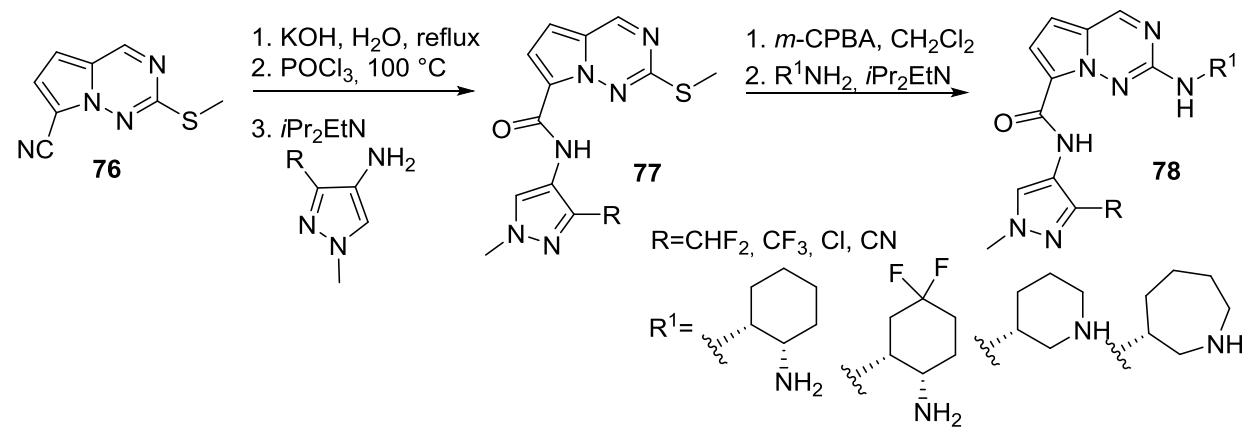

Scheme 11

Compound 80 has been synthesized by reaction of 5-methyl-4-(methylthio) pyrrolo[2,1$f][1,2,4]$ triazine 79 with: i) NBS followed by addition of 4-amino piperidine derivative; ii) oxidation of the $\mathrm{C}-4$ thiomethyl ether with $m$-CPBA followed by addition of anilines (Scheme 12). [69]

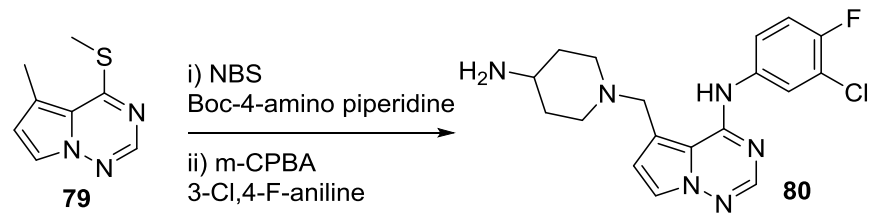

Scheme 12 
The majority of the references deal with the C-6 and C-7 substitution of the pyrrolo[2,1$f][1,2,4]$ triazines. The C-6 position of compounds $\mathbf{8 1}$ is frequently substituted with an ester that undergoes saponification to carboxylic acid (compounds 82). This latter is generally coupled with amines giving the corresponding amides 83 such as for example 36b [47], 36c [49], BMS-582949 36e [48], and 67a [64]. (Scheme 13, eq. a). Alternatively, a sequence including Curtius rearrangement in the presence of diphenylphosphoryl azide (DPPA) and reaction of the isocyanate intermediate with alcohols, yields a serie of carbamates 84 such as for instance 84a [47], and BMS-599626 84b [63] (Scheme 13, eq. b). Another example consists in the preparation of ketones 85 on one hand by reduction of the ester directly to aldehyde, followed by addition of the appropriate organo magnesium bromide and oxidation or on the other hand by conversion of the ester into acyl chloride followed by Friedel-Crafts acylation; as an example see 85a [50] (Scheme 13, eq. c). Finally, hydrazides $\mathbf{8 6}$ can be obtained from esters by known procedures and transformed into oxadiazole ring 87 by treatment with 2-chloroacetyl chloride followed by heating in neat $\mathrm{POCl}_{3}$, see compound 87a [61] (Scheme 13, eq. d). Only one example has been reported on the synthesis of carbon-11labeled pyrrolo[2,1-f][1,2,4]triazines 88 prepared from the carboxylic acid in presence of $\left[{ }^{11} \mathrm{C}\right] \mathrm{CH}_{3} \mathrm{OTf}$ through $0-\left[{ }^{11} \mathrm{C}\right]$ methylation to give compound 88 a (Scheme 13, eq. e). [70]

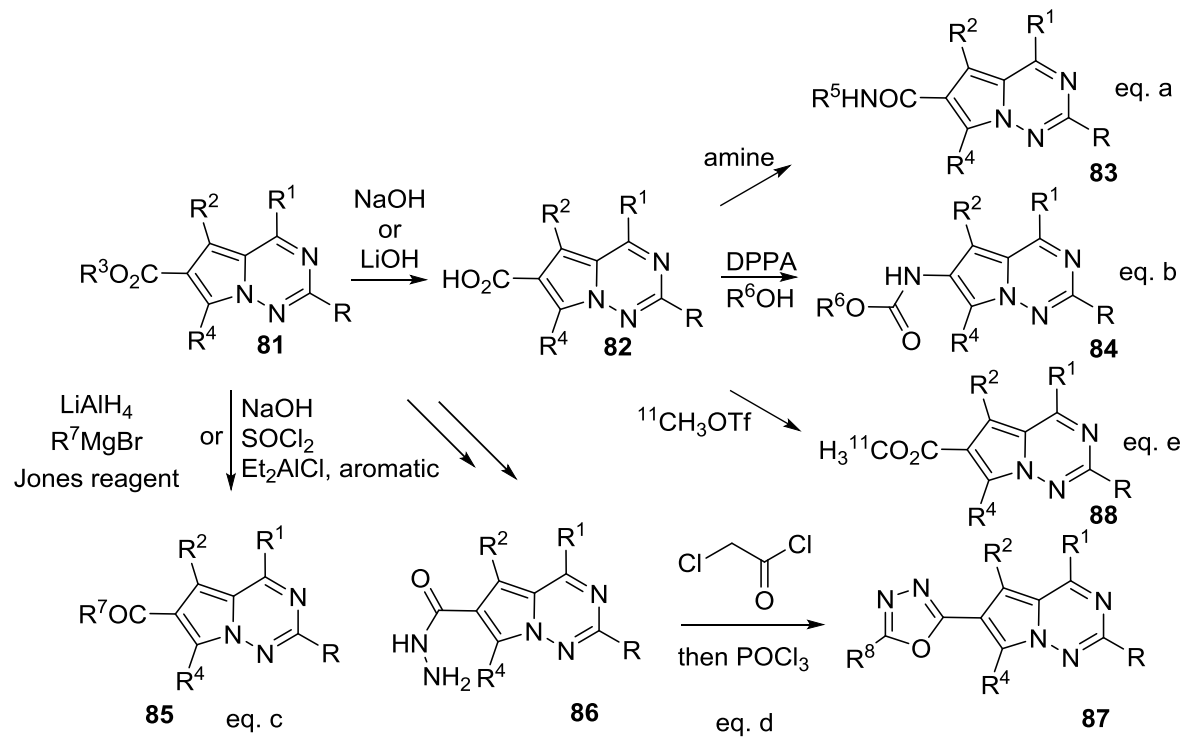

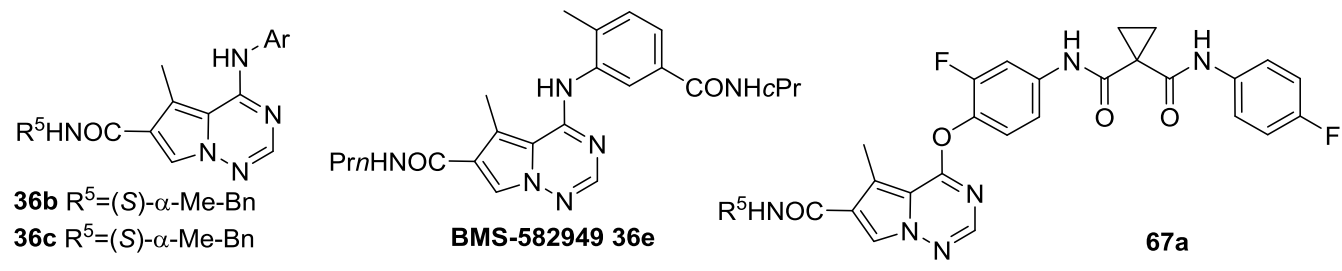

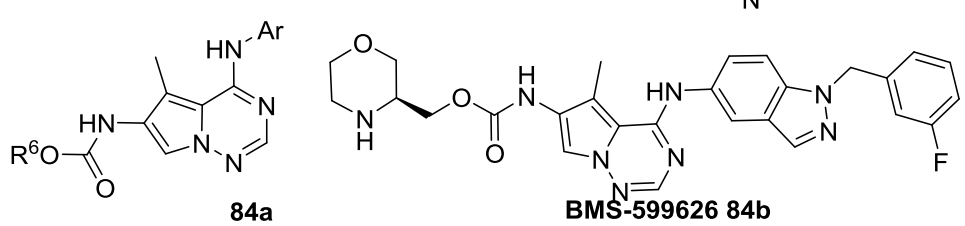

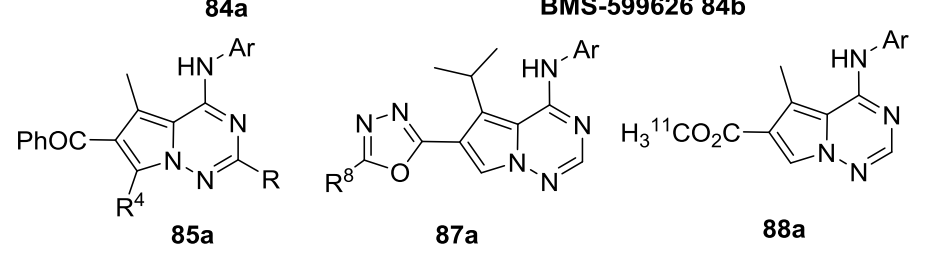


Several analogues of compound 67 a modified on the C-6 position have been obtained by transformation of the ethyl ester group into alcohol by Grignard reaction followed by Baeyer-Villiger rearrangement to give the intermediate $\mathbf{6 7 b}$. Further decoration of the C-6 position relies basically on the $O$-alkylation and brings to molecules 67c-e (Scheme 14). [64]

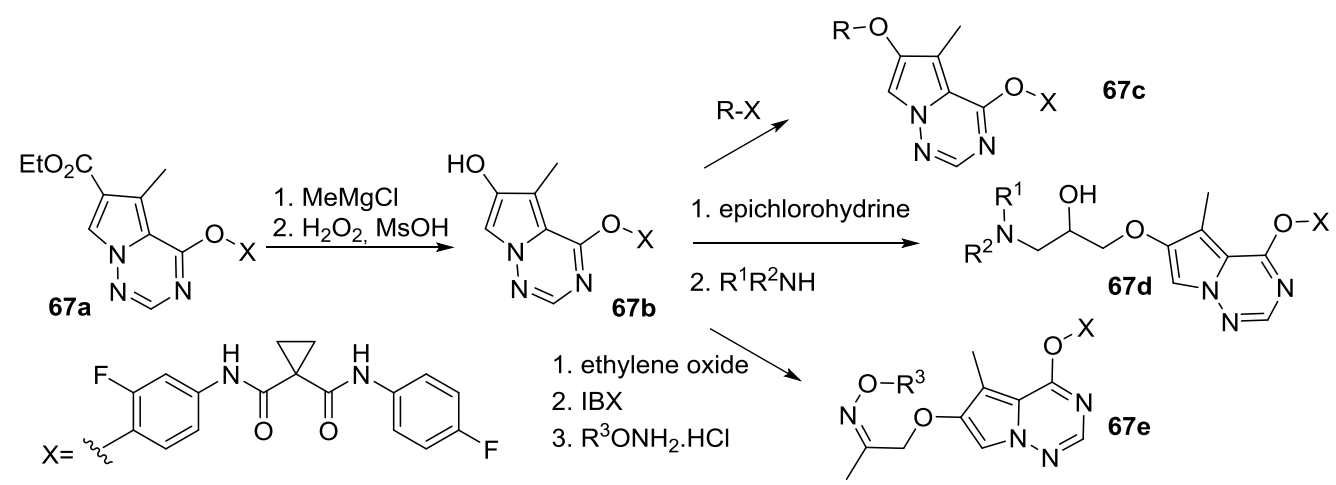

Scheme 14

Concerning the functionalization of the C-7 position the majority of the examples deal with the synthesis of C-nucleosides. The common strategy is to react the bromo or iodo derivative $\mathbf{8 9 a - b}$ with the ribonolactone 90 in order to obtain the hemiketal intermediate 91 (Scheme 15). [71] This latter undergoes different reaction to introduce several groups such as the $\mathrm{CN}$ group, for the most popular compounds in terms of biological activity see GS-6620 33 and GS-5734 34, figure 2.

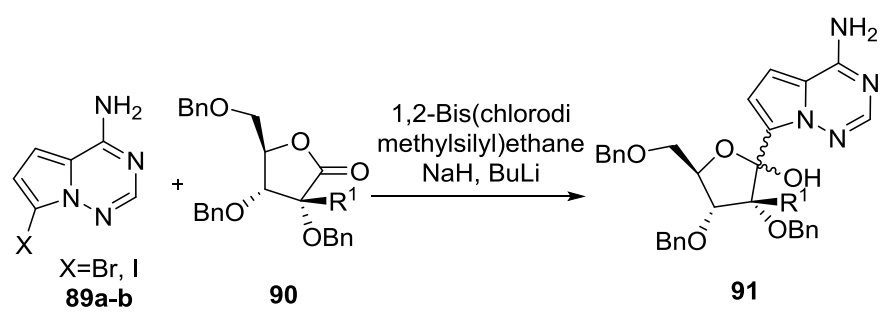

Scheme 15

2'-deoxy and 2',3'-dideoxyribosyl C-nucleosides 93a-c have also been synthesized by Heck-type coupling between glycal 92 and the 7-iodo pyrrolo[2,1-f][1,2,4]triazine 89b (Scheme 16). [72]

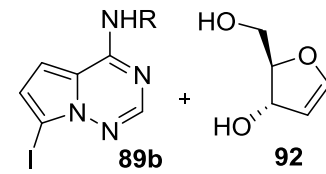

bis(dibenzylideneacetone) $\mathrm{Pd}(0)$
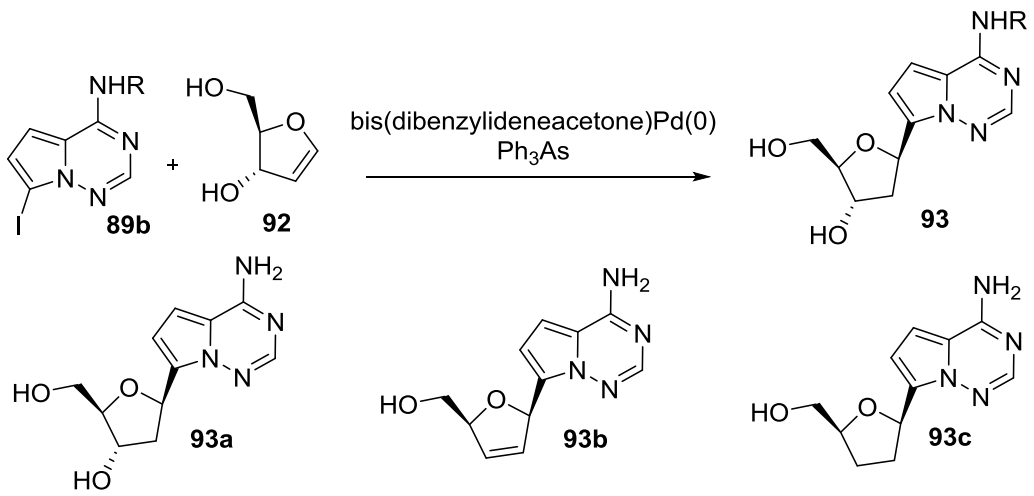

Scheme 16 
Two examples concern the $S$-alkylation of the pyrrolo[1,2- $d][1,2,4]$ triazine 94 . Compounds 96 were obtained in one step by reaction with 2-chloro acetamide derivatives or via a two steps procedure involving the reaction with chloroacetic acid to deliver the intermediate $\mathbf{9 5}$ followed by amidation with different amines in the presence of $\mathrm{N}, \mathrm{N}$-carbonylimidazole (CDI) in globally lower yields (Scheme 17). [73]

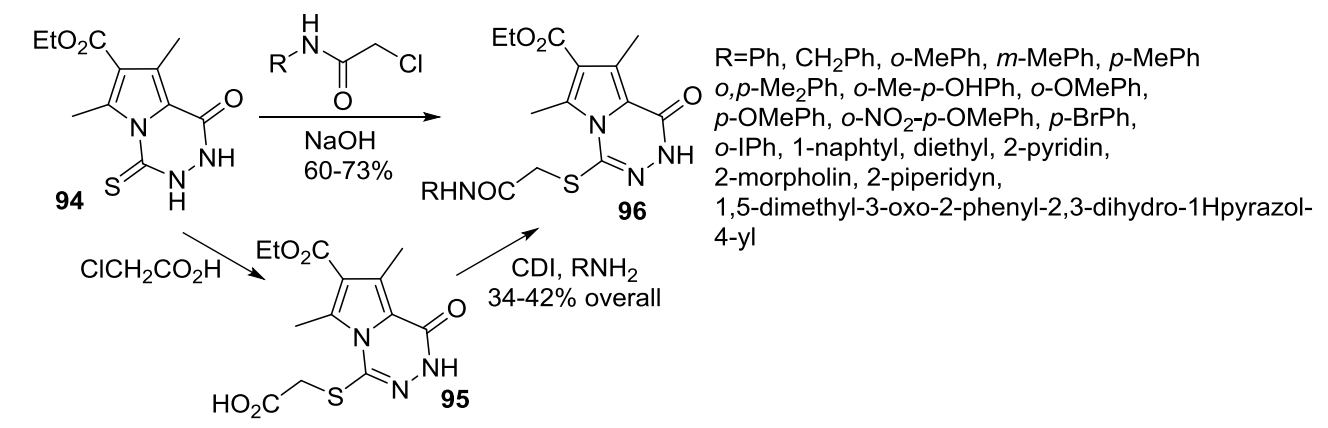

Scheme 17

Furo[2', $\left.3^{\prime}: 4,5\right]$ pyrrolo[1,2- $\left.d\right][1,2,4]$ triazin-8(7H)-thione 97 can cyclize upon reaction with hydrazine to deliver the triazino-triazinone 98 (Scheme 18). [67]
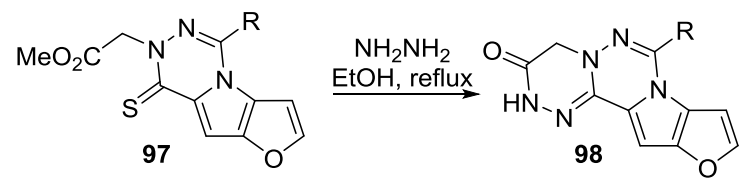

Scheme 18

\section{RING SYNTHESES CLASSIFIED BY NUMBER OF RING ATOMS IN EACH COMPONENT}

\subsection{Pyrrolo[1,2-b][1,2,4]triazine}

6-(2-methoxyphenyl)-8-(2-oxoindolin-3-ylidene)-2,8-dihydropyrrolo[1,2-b][1,2,4]triazin-3(4H)-one 102 was synthesized in three steps starting from 3-(2-oxofuran-3(2H)-ylidene)indolin-2-one 99 . The reaction with hydrazine hydrate in refluxing pyridine in the presence of $\mathrm{POCl}_{3}$ gave in $53 \%$ yield the corresponding hydrazine $\mathbf{1 0 0}$ that was in turn alkylated with chloroacetylchloride to yield $64 \%$ of 101. The cyclization to deliver the dihydropyrrolo[1,2-b][1,2,4]triazinone skeleton was achieved in presence of ammonium acetate in acidic conditions (48\% yield) (Scheme 19). [74]
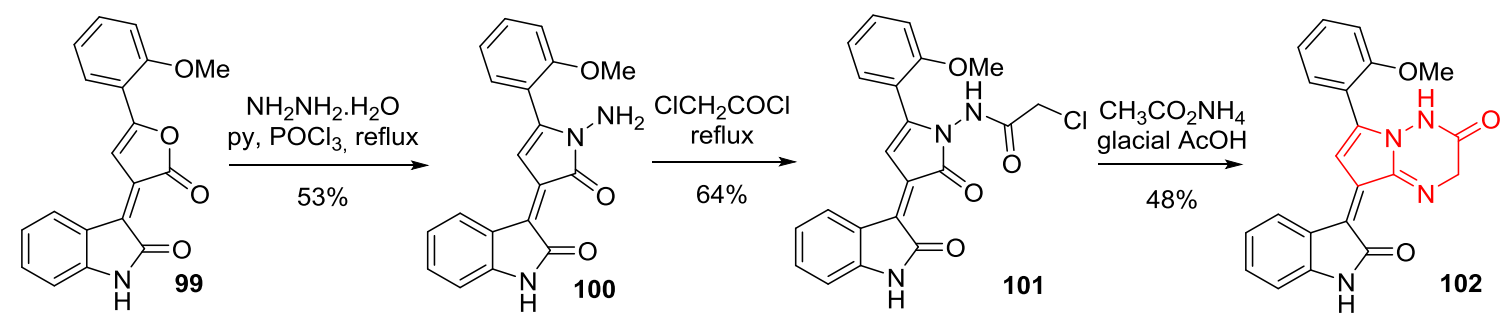

Scheme 19

\subsection{Pyrrolo[1,2-c][1,2,3]triazine}


This class of compounds was the less studied until 2009, when a group of scientists have generated a virtual exploratory heterocyclic library of small aromatic ring systems useful for the development of novel synthetic protein ligands. [75] This list includes pyrrolo[1,2-c][1,2,3]triazines which is an underor not yet explored class of heterocycles. In 2014 the synthesis of pyrido[3',2':4,5]pyrrolo[1,2c] $[1,2,3]$ benzotriazines 106 was described and involves the intramolecular cyclization of diazonium intermediates 105 generated in situ from anilines 104. These latter were synthesized by Chichibabin type reaction starting from commercially available 3-methylpyridine and 2-aminobenzonitriles to give anilines 103 , followed by transformations on the 3-position of the pyrrole ring in order to block the spontaneous cyclization of the diazonium on this position delivering the pyrrolocinnoline skeleton (Scheme 20). [76]

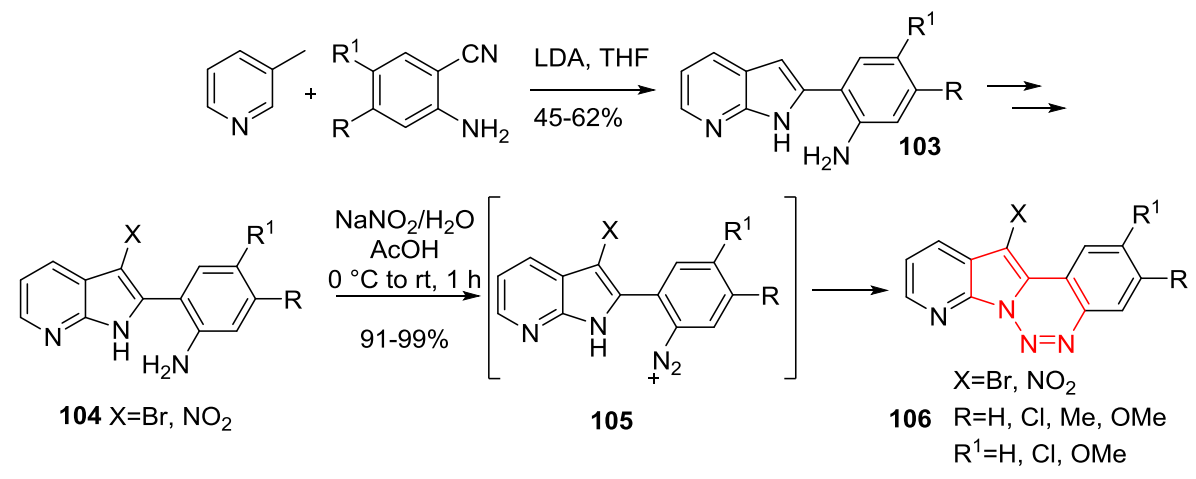

Scheme 20

$6 \pi$ electrocyclization of 2-indolo aniline 107 with tert-butyl nitrite gave pyrrolo[1,2c] $[1,2,3]$ benzotriazines 108 in $40 \%$ yield. tert-butyl nitrite plays the dual role of $N$ source and oxidant. (Scheme 21). [77]

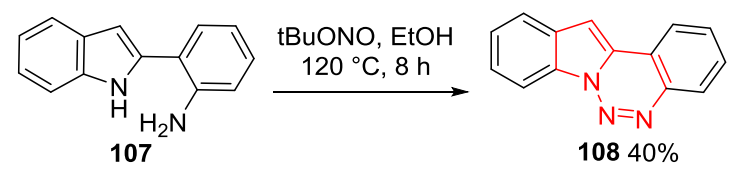

Scheme 21

\subsection{Pyrrolo[2,1-f][1,2,4]triazine}

Together with pyrrolo[2,1-d][1,2,4]triazines this is undoubtedly the most studied class of heterocycles falling within the scope of this chapter.

The synthesis of pyrrolo[2,1-f][1,2,4]triazines bringing C-2 carbon-linked proline isosteres such as pyrrolidin(on)e, cyclopentane and simple acyclic, has been achieved starting from the common 1amino-1H-pyrrole-2-carboxamide 109. A coupling reaction with the appropriate proline isostere in the presence of 1-ethyl-3-(3-dimethylaminopropyl)carbodiimide (EDC) delivered the intermediate 110 that undergoes cyclization, upon treatment with refluxing ethanolic $\mathrm{KOH}$ solution, to give compound 111 (Scheme 22). [52] Examples of biologically relevant compounds prepared with this methodology are compounds $37 \mathrm{~b}-\mathbf{f}$. 


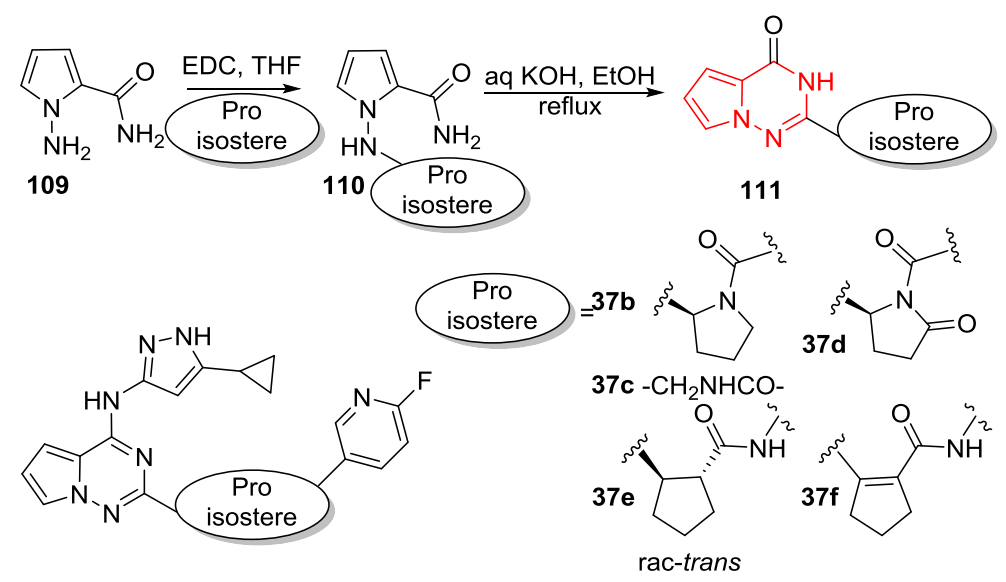

Scheme 22

Pyrrolo[2,1-f][1,2,4]triazine 115 substituted in C-2 and C-7 positions have been synthesized starting from methyl-2-pyrrole carboxylate $\mathbf{1 1 2}$. Treatment of $\mathbf{1 1 2}$ with chloramine followed by the addition of benzoylisothiocyanate yielded $65 \%$ of $\mathbf{1 1 3}$, which cyclizes into 68 upon basic hydrolysis. After the modifications in the C-4 and C-7 positions, discussed above in the paragraphs 5.32 and 6.12 , the oxidation of the sulphide to sulfoxide with $m$-CPBA gave 114. Follow the hydrolysis step to lead to 115 in 77\% yield (Scheme 23). The development of a scalable process has also been established starting from 116 which was converted into the dibrominated 117 in the presence of 5,5-dimethyl1,3-dibromohydantoine (DBH) in $87 \%$ yield. The halogen-metal exchange in the presence of the Knochel "Turbo Grignard" followed by quenching with DMF selectively gave $\mathbf{1 1 8}$ in $\mathbf{8 1 \%}$ yield. Suzuki coupling with only $0.5 \mathrm{~mol} \%$ of $\mathrm{Pd}$ catalyst in aqueous $\mathrm{EtOH}$ gave 119. The cyclization to obtain the pyrrolo[2,1-f][1,2,4]triazine core 115 takes place after treatment with NaHMDS and addition of phenyl chloroformate, by the action of a Lewis acid, namely $\mathrm{Sc}(\mathrm{OTf})_{3}$, followed by addition of ammonium carbonate (Scheme 23). [65]

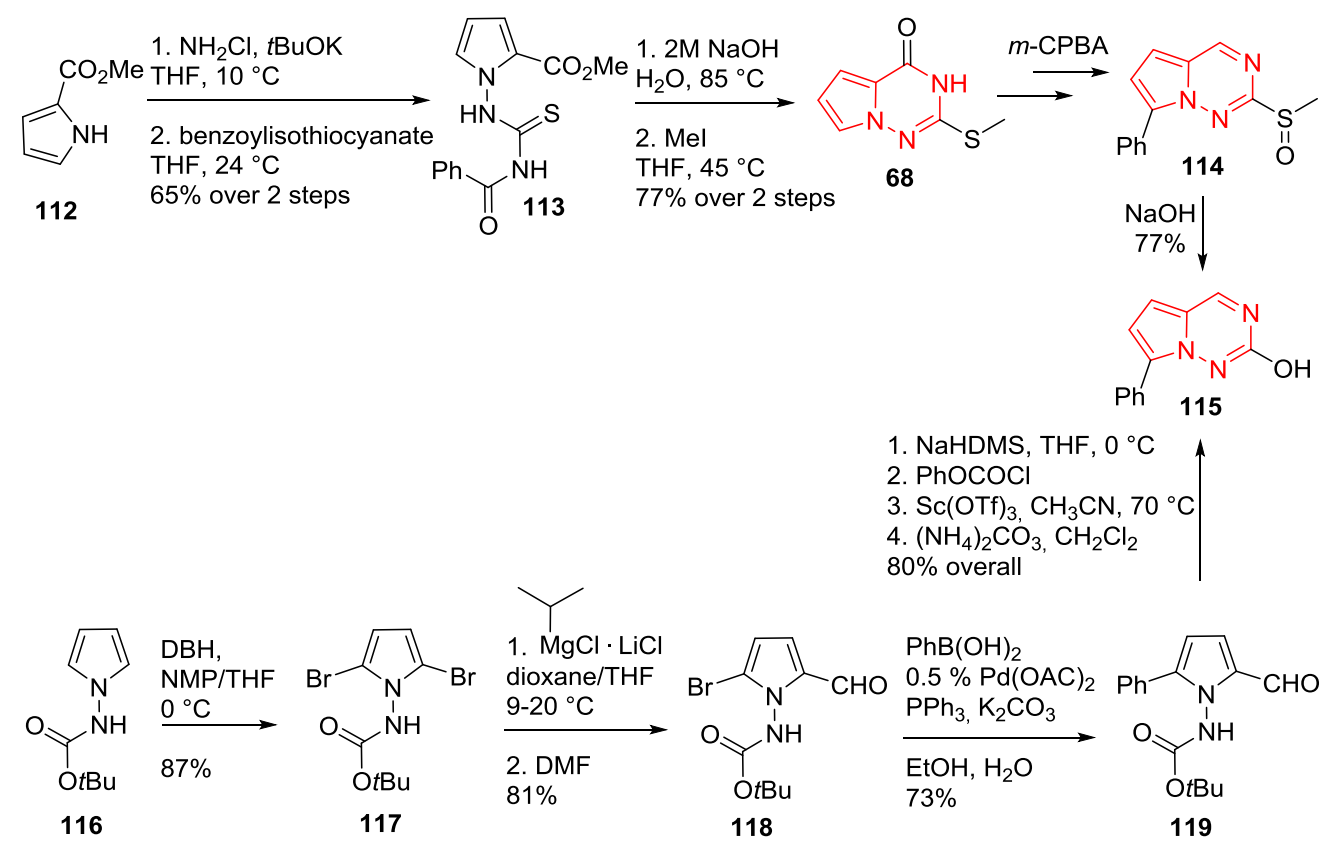

Scheme 23 
A $\mathrm{kg}$ scale synthesis of functionalized pyrrolotriazine 124, as intermediate building block in the synthesis of BMS 690514125 [46] [47] [61] and analogues, as potent anticancer agents, has been established. [78] Bromohydrazone intermediate $\mathbf{1 2 0}$ was obtained in $550 \mathrm{Kg}$ over five batches by condensation of commercially available bromoacetal and Cbz-hydrazine in the presence of $\mathrm{H}_{3} \mathrm{PO}_{4}$. The following alkylation in the presence of acetic acid delivered the intermediate 121 which undergoes cyclization to pyrrole $\mathbf{1 2 2}$ in acidic conditions $(p-\mathrm{TsOH})$ in $\mathbf{7 8 \%}$ yield over two steps. The deprotection of the $\mathrm{Cbz}$ group was achieved in standard $10 \% \mathrm{Pd} / \mathrm{C}$ and $\mathrm{H}_{2}$ conditions. For stability reasons the amine $\mathbf{1 2 3}$ was recovered as methylsulfonate salt in $80 \%$ yield over two steps. Acid catalysed annulation of $\mathbf{1 2 3}$ with formamidine acetate provided the key pyrrolotriazine ester $\mathbf{1 2 4}$ in $92 \%$ yield (Scheme 24$)$.

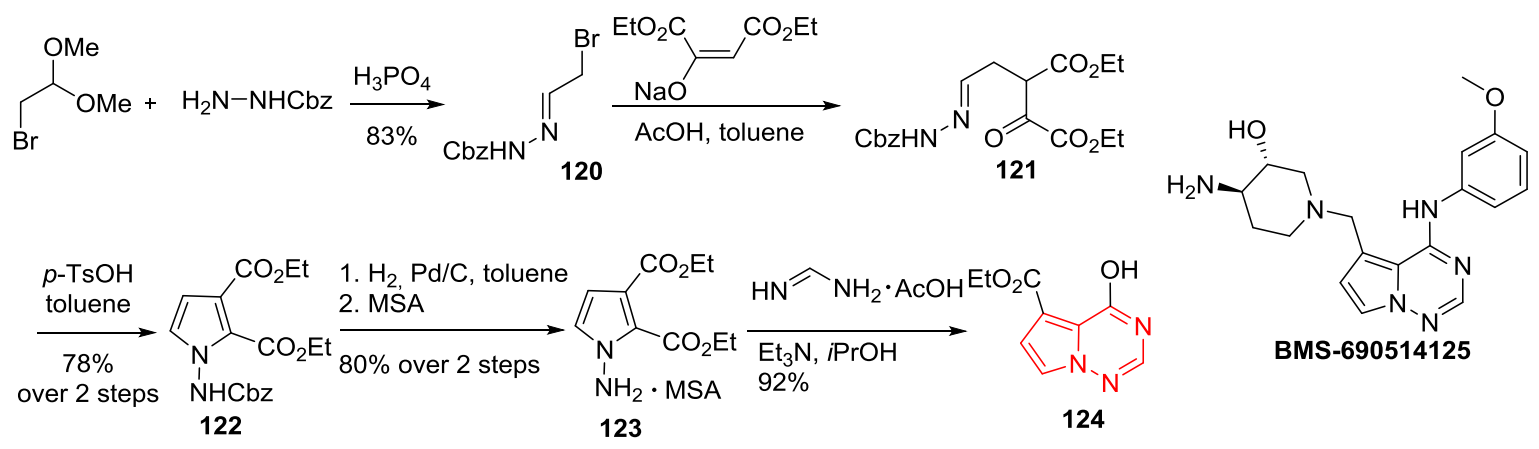

Scheme 24

4-(2-arylpyrido[3',2':3,4]pyrrolo[1,2-f][1,2,4]-triazine 129 was synthesized following scheme 8.35 . Starting from 2-chloro-3-nitropyridine $\mathbf{1 2 6}$ the $1 \mathrm{H}$-pyrrolo[3,2-b]pyridine skeleton $\mathbf{1 2 7}$ was formed in three steps in $43 \%$ overall yield. The hydrazine function was installed by treatment with chloramine and intermediate $\mathbf{1 2 8}$ was submitted to annulation in the presence of ethyl 3-methoxybenzimidate hydrochloride in refluxing ethanol to deliver 129 in only $26 \%$ yield (Scheme 25). [62].

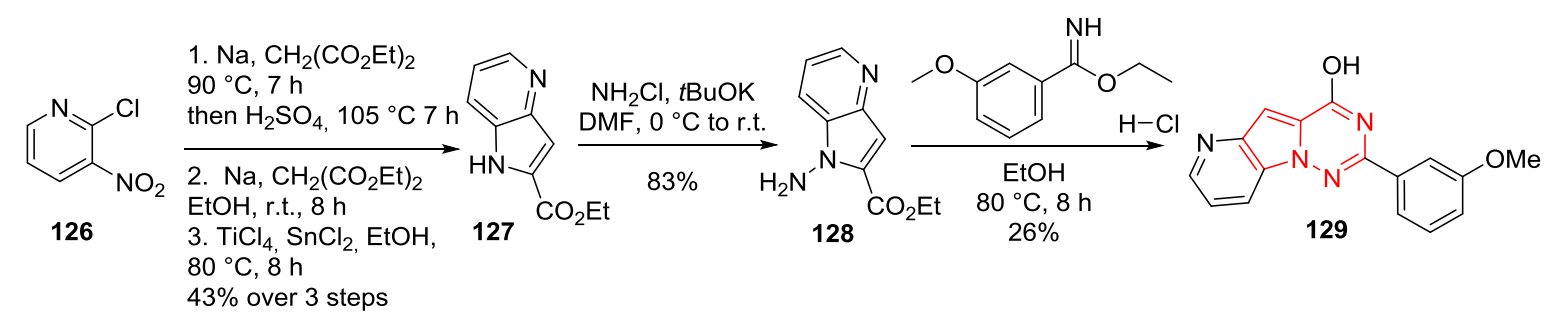

Scheme 25

The synthesis of substituted pyrrolo[2,1-f]triazin-4(3H)-ones 137 has been achieved from intermediate 131 or the unsymmetrical 134. The synthesis of 131 is depicted in scheme 26, eq. a, and relies on the addition of Grignard reagent on the 2-methylpyrrole-4-carboxylate 130, followed by reduction with lithium aluminium hydride. The synthesis of unsymmetrical 134, bearing three different substituents on the C-3 of the pyrrole unit, is described in scheme 26, eq. b. 2methylbutanal 132 was submitted to Wittig reaction in the presence of the appropriate phosphorane, follow the addition of ethyl nitroacetate, reduction of the nitro group and intramolecular cyclisation to get the pyrrole ring 133.The alkaline hydrolysis and decarboxylation gave 134. $C$-acylation with triphosgene followed by addition of different amines resulted in the amides $\mathbf{1 3 5}$. $\mathbf{N}$-amination to give $\mathbf{1 3 6}$ was achieved with chloroamine and finally the cyclization step 
to obtain the pyrrolotriazine core 137 was carried out with arylaldehydes in the presence of $\mathrm{O}_{2}$ and activated charcoal Darco-KB. [79]<smiles>[R]C(C)c1c[nH]c(C=CC(=O)OCC)c1</smiles>

$\mathrm{R}=\mathrm{R}^{1}=\mathrm{Me}, \mathrm{Et}$ or $\mathrm{R}=\mathrm{Me}$ and $\mathrm{R}^{1}=\mathrm{Et}$ $\mathrm{R}^{2}=\mathrm{H}, \mathrm{Me}, \mathrm{Et},\left(\mathrm{CH}_{2}\right)_{2} \mathrm{OH}, \mathrm{Pr}, \mathrm{CPr}, \mathrm{CH}_{2} \mathrm{Pr}, \mathrm{CH}_{2} \mathrm{CPr}$<smiles>COc1ccc(C)c(Cl)c1</smiles><smiles>COc1cc(C)c(C(C)C)c(C)c1</smiles>

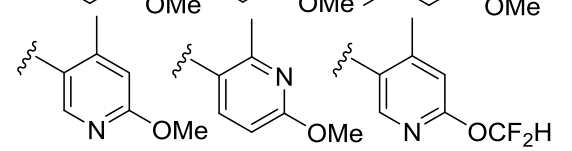

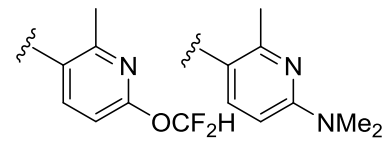

Scheme 26

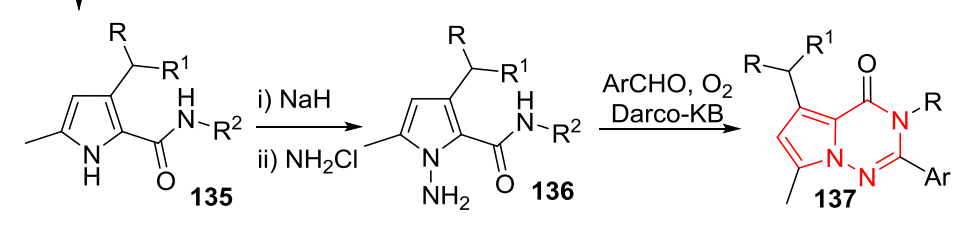

i) $\mathrm{ClCOCCl}_{3}$

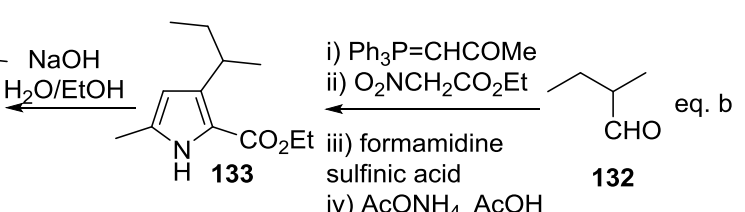

iv) $\mathrm{AcONH}_{4}, \mathrm{AcOH}$

2-substituted pyrrolo[2,1-f][1,2,4]triazin-4(3H)-ones 141-142 have been synthesized by pot, atom, step economic and six bond forming reaction. The reaction of pyrrolo carboxamides 138 with substituted 4-oxo-4H-chromene-3-carbaldehyde 139 is catalysed by $\mathrm{Cu}(\mathrm{II})$ in DMSO to deliver intermediate $\mathbf{1 4 0}$ which reacts with benzamidines or hydrazines to give the final compounds 141142 respectively (Scheme 27$)$. [41]

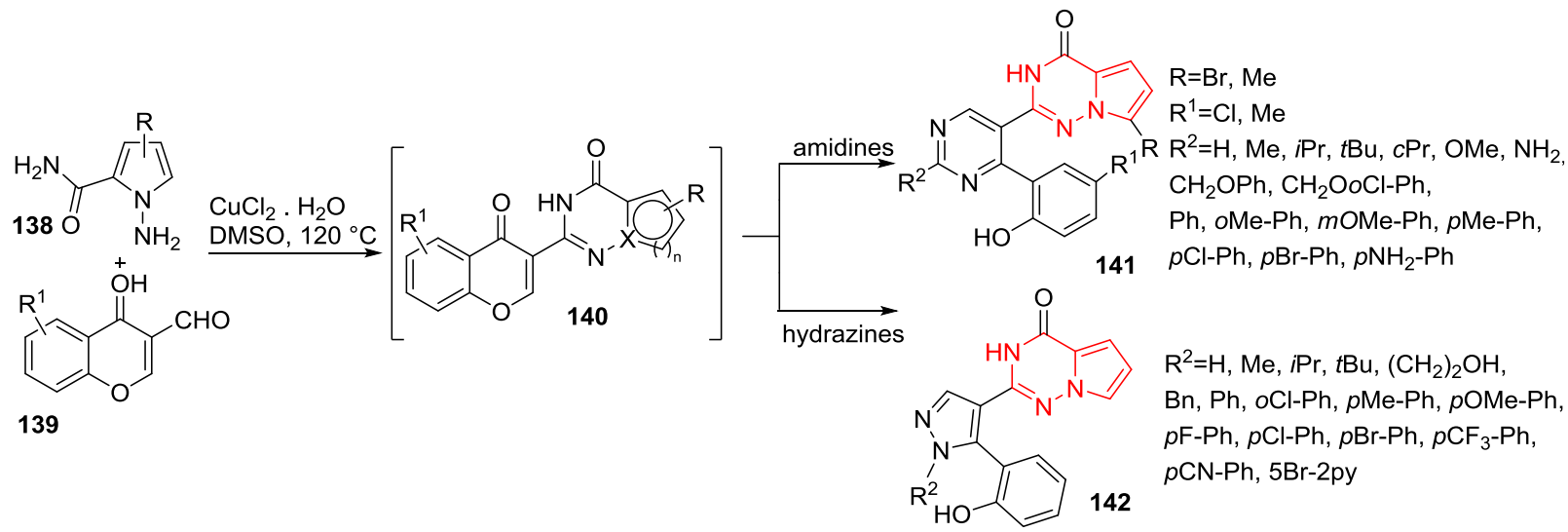

Scheme 27

A variant to this reaction relies on copper(II) promoted annulation of pyrrolo carboxamides $\mathbf{1 3 8}$ with different aldehydes and acetals, to yield compounds 143 as shown in scheme 28, eq. a. [80] With the same strategy more complex pyrrolo[2,1-f][1,2,4]triazines fused to isoquinolines 144 were also obtained when using 2-ethynylbenzaldehyde derivatives 144 (Scheme 28, eq. b). [42] 


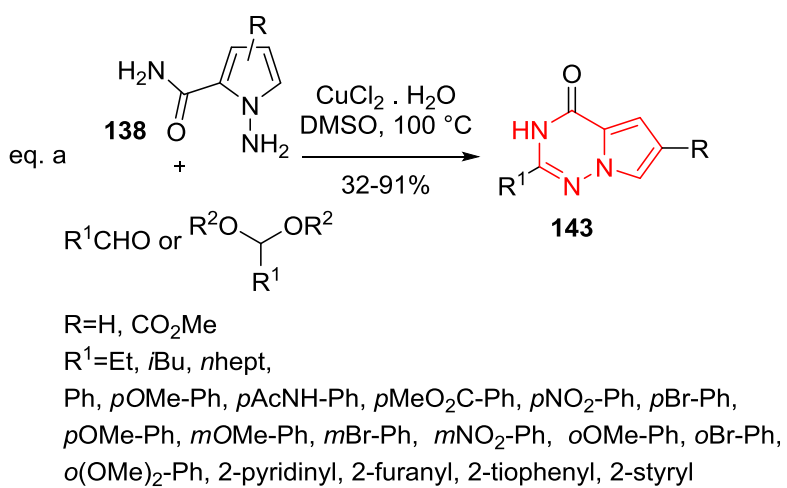

Scheme 28

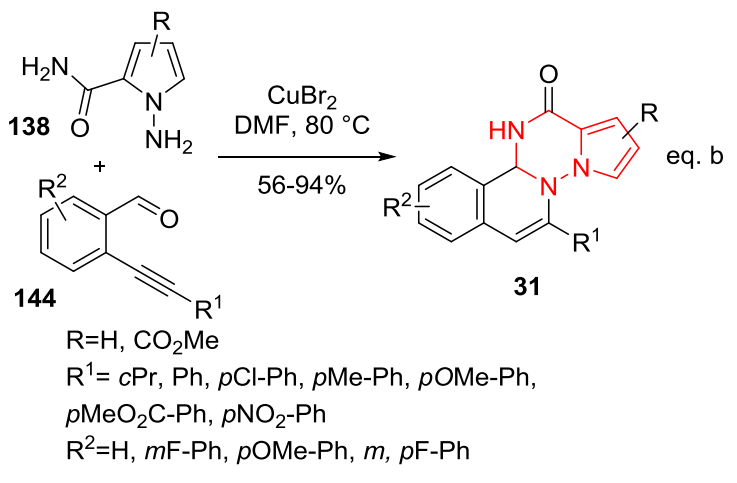

Pyrrolotriazine C-nucleosides with increased anti-hepatitis C virus (HCV) activities were synthesized following a linear route starting from riboside 145. After protection of the different hydroxy groups the activated trichloroacetimidate $\mathbf{1 4 6}$ was obtained. Addition of the pyrrole in the presence of $\mathrm{BF}_{3} \cdot \mathrm{Et}_{2} \mathrm{O}$ delivered an anomeric mixture of the pyrrolo-nucleosides 147 , which were submitted to reaction with chlorosulfonyl isocyanate to give the pyrrolonitrile nucleoside 148 . $\mathrm{N}$-amination of the desired $\beta$-anomer, to deliver $\mathbf{1 4 9}$, followed by ring closure with formamidine acetate, yielded the adenosine analogue 91a. [71d] Alternatively ring closure by condensation with guanidine carbonate after deprotection delivered the 2,6-diamino-pyrrolotriazine nucleoside 91b. Finally, intermediate 148 was also decorated with a $\mathrm{F}$ atom on the 3-position of the pyrrole ring before proceeding to the $\mathrm{N}$-amination that allowed the synthesis of the intermediate $\mathbf{1 5 0}$. This last underwent ring closure and deprotection to give compound 91c (Scheme 29). [71c-d]

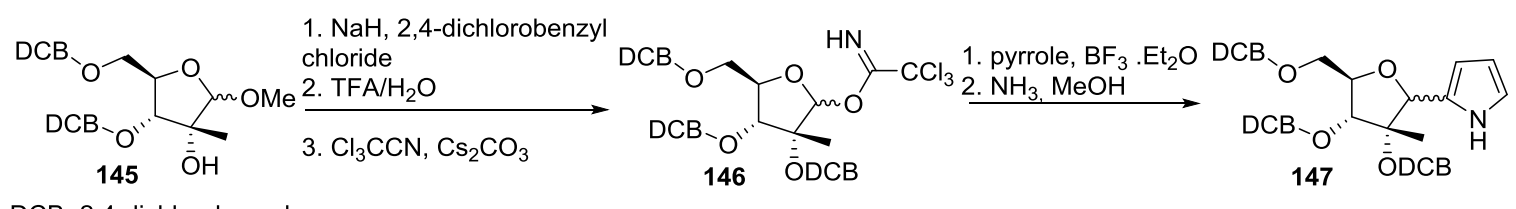

$\mathrm{DCB}=2,4$-dichlorobenzyl

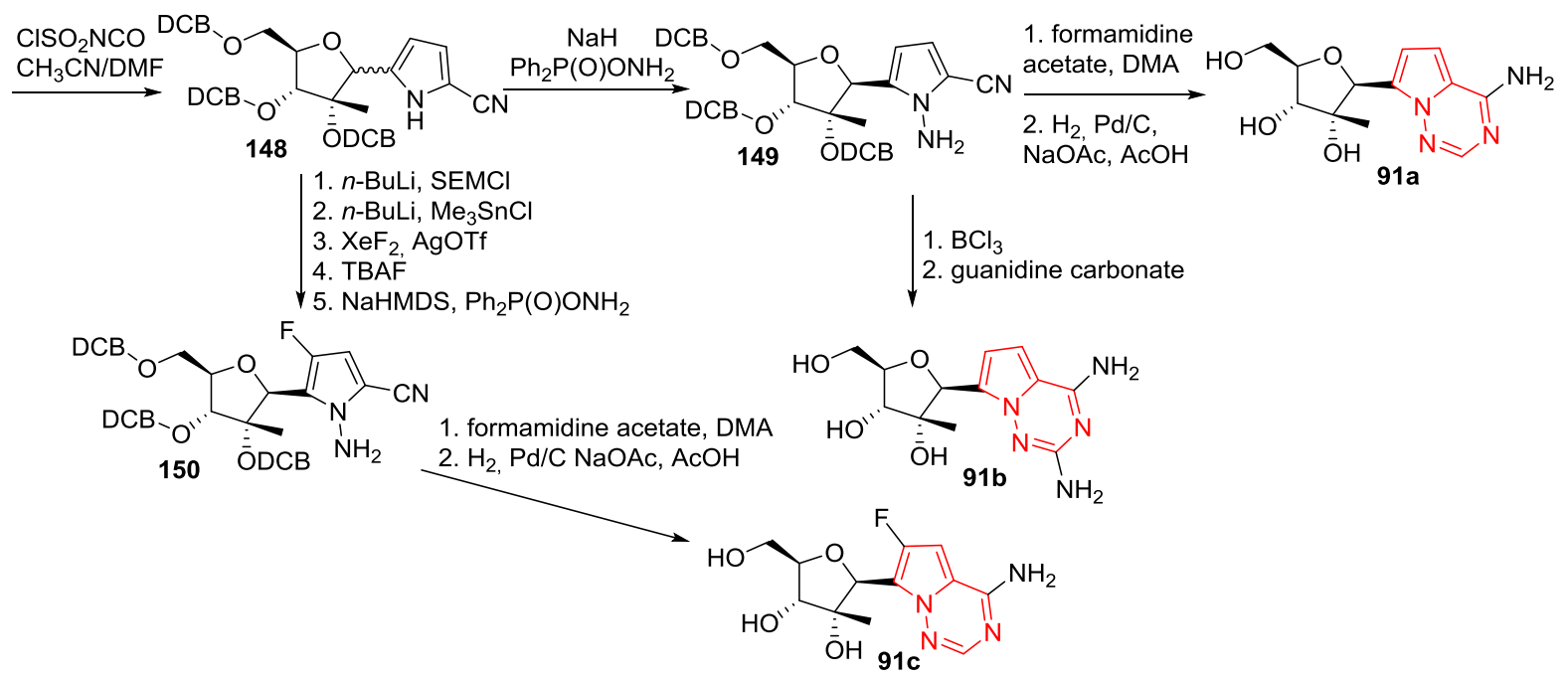

Scheme 29 
C-7 substituted pyrrolo[2,1-f][1,2,4]triazine 76 was obtained from 3-(methylsulfanyl)-1,2,4-triazine 151 by treatment with tetracyanoethylene oxide, to yield $83 \%$ of 152 , followed by $[2+3]$ cycloaddition with phenyl vinyl sulfoxide (Scheme 30). [68]

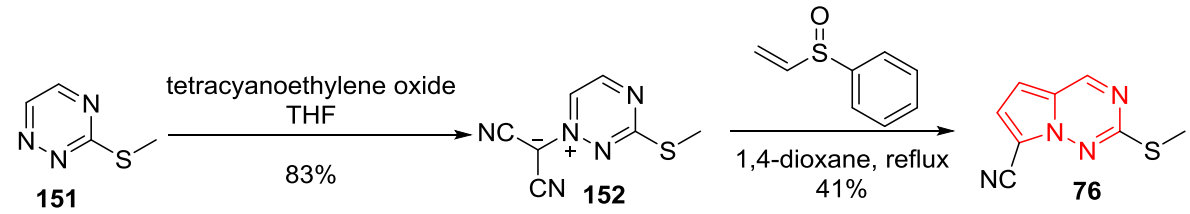

Scheme 30

Reaction of ethyl 2-isocyanoacetate and acetaldehyde in the presence of 1,8diazabicyclo[5.4.0] undec-7-ene (DBU) gave the substituted pyrrole skeleton 153, which undergoes then $\mathrm{N}$-alkylation in the presence of chloramine to give 154 . Its reaction with formamide allowed the synthesis of C-5 and C-6 substituted dihydropyrrolo[2,1-f][1,2,4]triazinone core 155 (Scheme 31). [64]

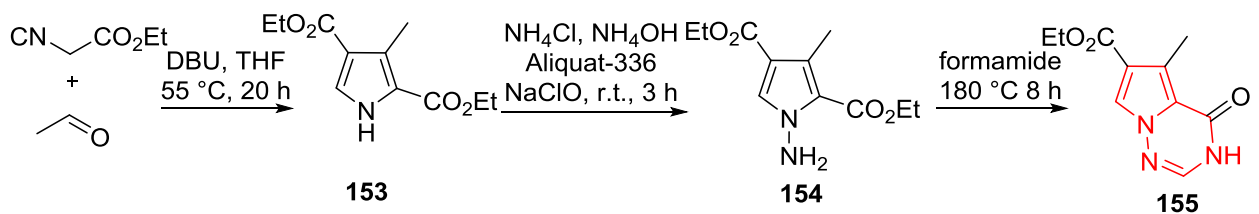

Scheme 31

\subsection{Pyrrolo[1,2-c][1,2,4]triazine}

The synthesis of 1,3-diphenyl-6,7,8,8a-tetrahydropyrrolo[2,1-c]-1,2,4-triazine-4(1H)-thione 157 has been reported starting from sulfanyl derivatives of pyrrolidinium salts 156, in the presence of cesium carbonate, via an intramolecular cyclization (Scheme 32). [81]

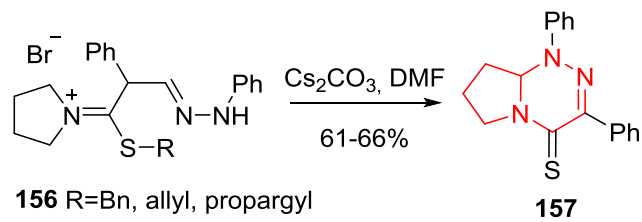

Scheme 32

Indole[1,2-c][1,2,4]triazines 161 were obtained by a three steps procedure involving the reaction of substituted indole derivatives 158 with 2-nitrophenyl halides 159 in the presence of cesium carbonate, and reduction of the nitro group into amine operated by $\mathrm{SnCl}_{2}$, to yield $\mathbf{1 6 0}$. Modified intramolecular Sandmeyer reaction in the presence of tert-butylnitrite gave the desired $\mathbf{1 6 1}$ (Scheme 33). [82] 


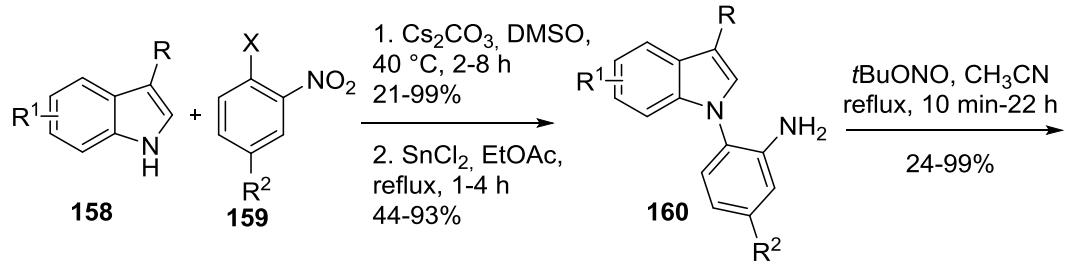

Scheme 33.

2,8-dihydropyrrolo[2,1-c][1,2,4]triazin-3(4H)-ones 164a-b have been obtained by transformation of $2(3 \mathrm{H})$-furanones 162 via opening of the lactone and formation of the lactam ring 163 in the presence of glycine in acidic conditions. The carboxylic acid was then used for the construction of the triazinone ring by treatment with hydrazine upon activation in the presence of $\mathrm{SOCl}_{2}$ (Scheme 34). [83]

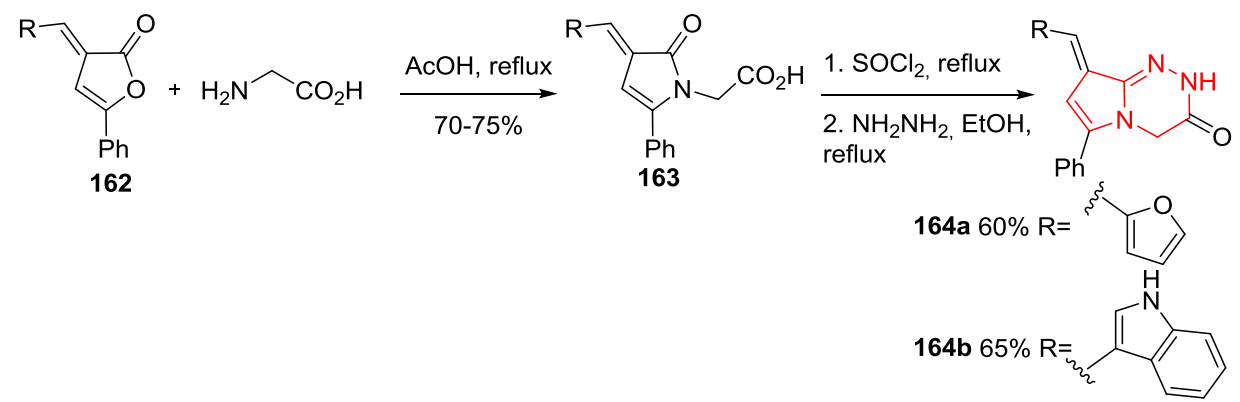

Scheme 34

Indole $[1,2,4]$ triazin-dione $\mathbf{1 6 7}$ has been synthesized starting from isatin- $N$-acetyl chloride $\mathbf{1 6 5}$ by reaction with hydrazine hydrate in refluxing benzene to yield $88 \%$ of the corresponding hydrazide 166. The cyclization into indole-triazine was achieved by refluxing in acetic anhydride in $68 \%$ yield (Scheme 35). [84]<smiles>O=C(Cl)CN1C(=O)C(=O)c2ccccc21</smiles>

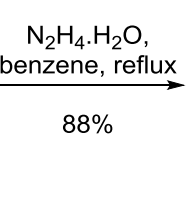<smiles>NNC(=O)CN1C(=O)C(=O)c2ccccc21</smiles><smiles></smiles>

Scheme 35

$6 \pi$ electrocyclization of 2-pyrrolo and 2-indolo anilines 168-169 with tert-butyl nitrite gave benzo[e]pyrrolo[2,1-c][1,2,4]benzotriazines 170 and 171 respectively, in good yields. Tert-butyl nitrite plays the dual role of $\mathrm{N}$ source and oxidant. (Scheme 36). [85] [77] 


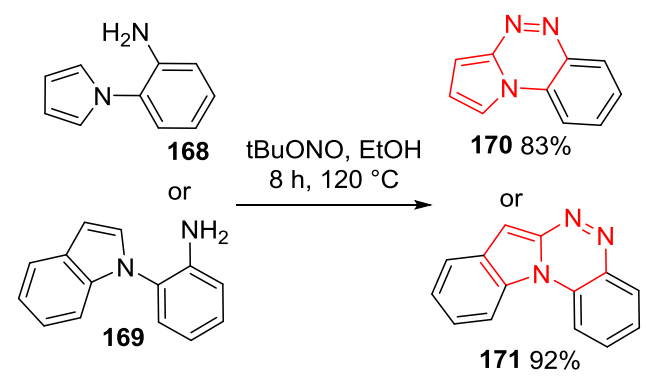

Scheme 36

\subsection{Pyrrolo[1,2- $a][1,3,5]$ triazine}

Triazinane diones 172 have been synthesized by a four component reaction (4CR) involving a phosphonate, different nitriles, aldehydes and isocyanates. The ring-closing metathesis (RCM) or cycloaddition reaction such as intramolecular Diels-Alder (IMDA) of intermediates $\mathbf{1 7 2}$ delivered the bicyclic skeleton of nonconjugated pyrrolo[1,2-a][1,3,5]triazines. With those methodologies, compounds 173 and 28a-c were respectively obtained (Scheme 37).[39]

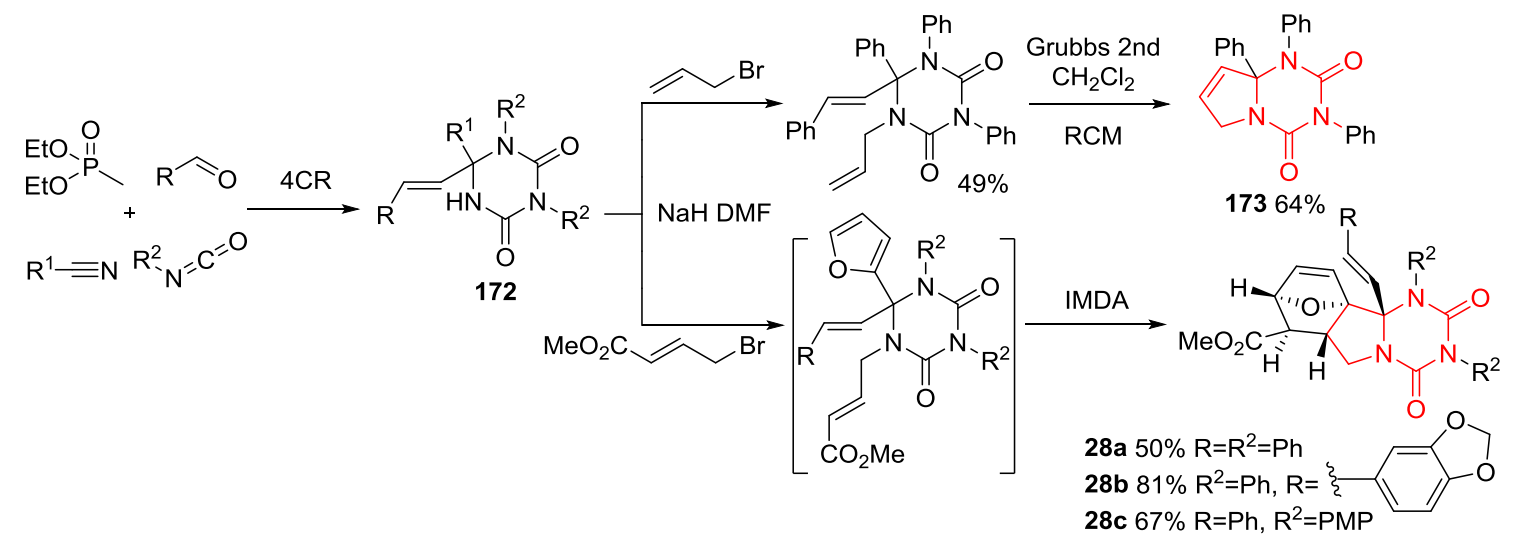

Scheme 37

The reactivity of $\mathrm{N}$-amidinothiourea $\mathbf{1 7 4}$ towards $o$-phtalaldehyde $\mathbf{1 7 5}$ have been studied. [86] The condensation of the amino group onto the aldehyde gave the azomethine intermediate 176. The attack of the azomethine $\mathrm{N}$ atom on the second carbonyl group gave the cyclic $\mathbf{1 7 7}$ which undergoes 1,3-hydride shift to deliver the adduct 178. Further cyclization yielded the isoindolo triazine scaffold 179. (Scheme 38).

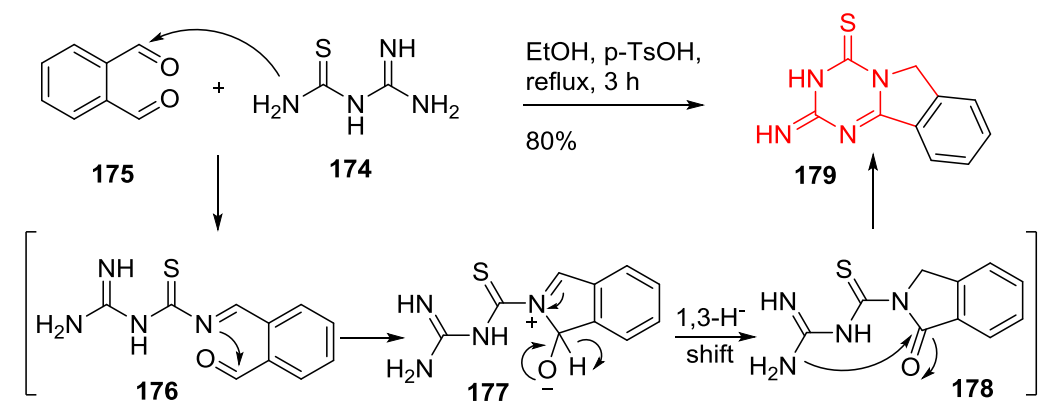

Scheme 38 
Direct arylation of $[1,3,5]$ triazine-2,4 $(1 \mathrm{H}, 3 \mathrm{H})$-dione 180 with mesitylene promoted by $\mathrm{AlCl}_{3}$ followed by oxidation in mild conditions yielded 8,10-dimethyl-1,10b-dihydro[1,3,5]triazino-[2,1-a]isoindole2,4,6(3H)-trione 182 via the intermediate 181 (Scheme 39). [87]

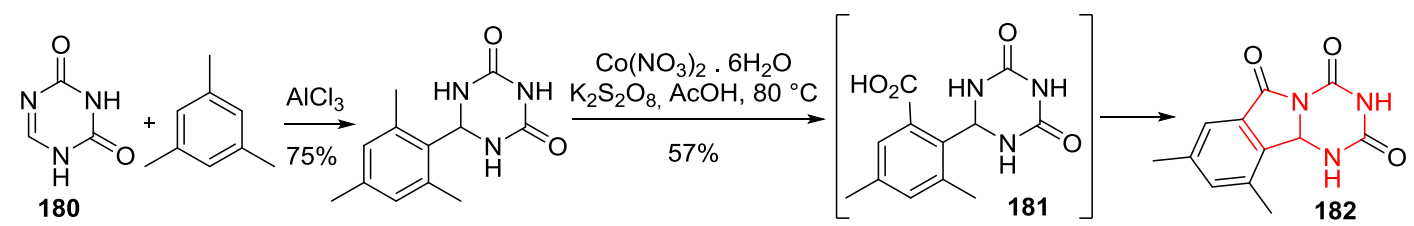

Scheme 39

\subsection{Pyrrolo[1,2-d][1,2,4]triazine}

In general, the 1,2,4-triazin-6-one skeleton has been constructed by two main strategies: the cyclocondensation of $\alpha$-aminocarbohydrazides with orthoesters or the cyclisation of $N$-thioacyl- $\alpha$ aminoesters with hydrazines.

Concerning the first route three examples have been described in the period covered by this chapter. 4-phenyl-6,7,8,8a-tetrahydropyrrolo[1,2-d][1,2,4]triazin-1(2H)-one 184 was obtained in $75 \%$ yield by reaction of proline hydrazide 183 with triethyl orthobenzoate in the presence of $p$ $\mathrm{TsOH}$. Partial racemisation occurred and this can be explained by the keto-enol tautomerism of the bicyclic $[1,2,4]$ triazin-6-one product (Scheme 40). [88]

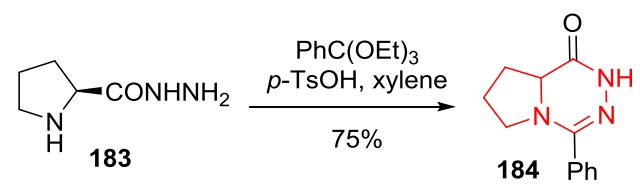

Scheme 40

Thieno- 185 and furo-pyrrole skeleton 186 undergo reaction with hydrazine to deliver the corresponding hydrazones $\mathbf{1 8 7}$ which were further cyclized in the presence of orthoesters to the tricyclic thieno 70 [66] and furo[2', 3':4,5]pyrrolo[1,2-d][1,2,4]triazinones 71 [57] [67]. Alternatively, the acetylation of the furo-pyrrole unit 186 followed by thionation yielded the $N$-thioacyl- $\alpha$ aminoesters $\mathbf{1 8 8}$ which undergoes cyclization upon treatment with hydrazine to give $\mathbf{7 1}$ as well (Scheme 41).

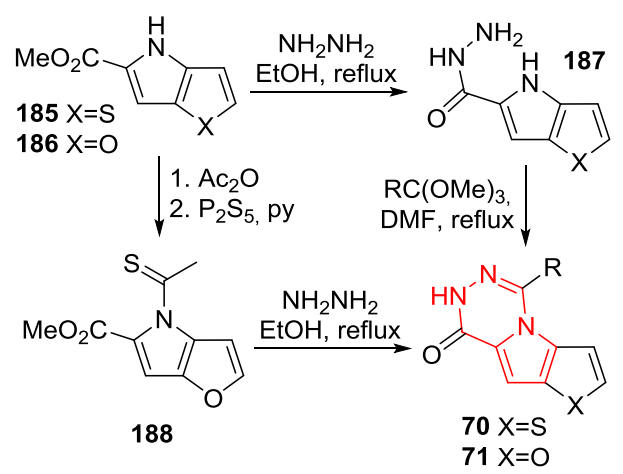

Scheme 41 
Other two examples of cyclisation of $N$-thioacyl- $\alpha$-aminoesters with hydrazines are described below. 5-methyoxicarbonyldesoxythiovasicinone 189 was reacted with hydrazide monohydrate to yield $94 \%$ of heterocycle 190 (Scheme 42). [89]
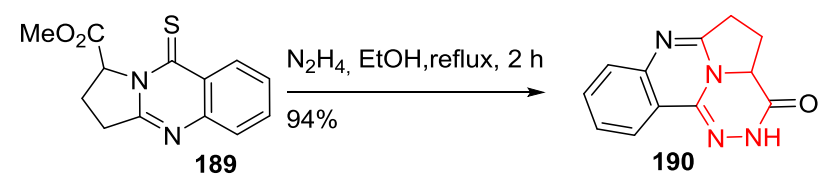

Scheme 42

The heterocyclization of hydrazide 191 by heating in EtOH in the presence of potassium(ethoxycarbonothioyl)sulphide delivered the pyrrolo[1,2- $d][1,2,4]$ triazine 94 in $92 \%$ yield (Scheme 43). [73]

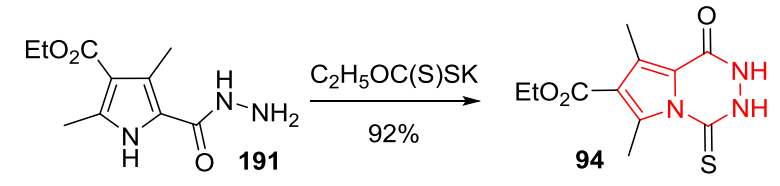

Scheme 43

Beyond these methods, more recently new routes to access the pyrrolo[1,2- $d][1,2,4]$ triazine core have been developed.

$1 H, 4 H$-pyrrolo[1,2- $d][1,2,4]$ triazines $194 a-c$ were obtained by a $[8 \pi+2 \pi]$ cycloaddition reaction of diethyl azodicarboxylate (DEAD) with azafulvenium methides 193, in situ generated from pyrrolo[1,2-c] thiazoles 192 under MW irradiation (Scheme 44). [90] [91]

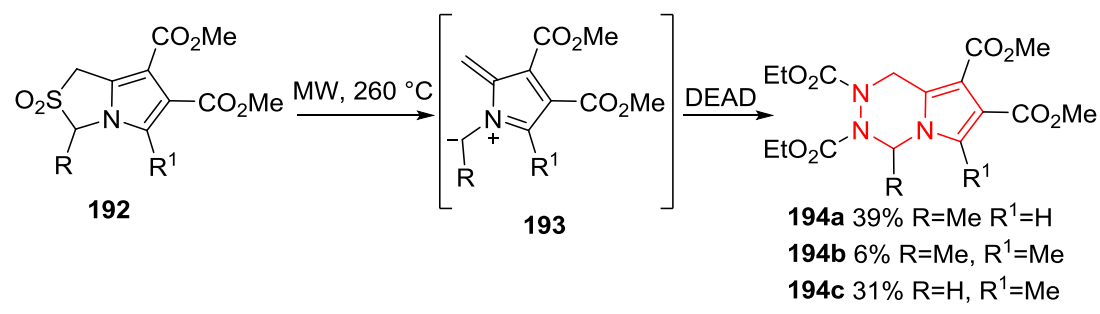

Scheme 44

Aza-diketopiperazines (aza-DKPS) have been synthesized starting from aza-dipeptides 199. These latter are obtained by reaction of diphenylhydrazone 195 activated by $p$-nitrophenyl chloroformate 196 and subsequent coupling of the resulting 197 with proline methyl ester. After alkylation of the benzophenone semicarbazone aza-dipeptide 198 with alkyl bromides in the presence of $t \mathrm{BuOK}$, the $\mathrm{N}$-terminal deprotection of the aza-dipeptides 199 in $\mathrm{HCl} / \mathrm{THF}$ yielded the cyclic azadiketopiperazines 200a-c (Scheme 45). [92] 


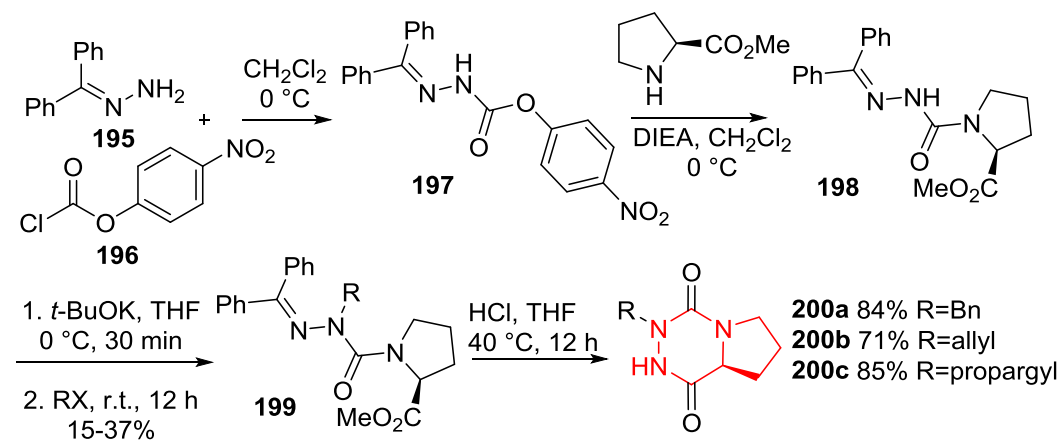

Scheme 45

Aza-DKPs 200 have been also synthesized thanks to solution- and solid-phase strategies via semicarbazides key intermediates 201 and 202. Concerning the solution-phase approach (Scheme 46, eq. a), two steps are involved in the formation of the target $c$-[aza-alkylGly-Pro] derivatives: coupling of proline ester with Boc-carbazates, in the presence of bis(trichloromethyl)carbonate (BTC) as activation reagent, to deliver the semicarbazides 201, concomitant deprotection of the Boc group and cyclization in the presence of Amberlist 15 resin. The solid-phase strategy relies on the use of Wang-PS resin in order to have access to 200a and 200d-I. Following the same sequence as in solution-phase, the semicarbazide intermediate $\mathbf{2 0 2}$ is obtained and readily submitted to cleavage and cyclization by treatment with TFA/ $\mathrm{H}_{2} \mathrm{O}$ (95/5) (Scheme 46, eq. B). [93] Comparison of the three methods reveal that, at least for aza-DKP 200a, the first methodology [92] is more powerful (84\%) than the solid-phase approach (eq. b 78\%) and that the route a gave the less good yields (eq. a 55\%).

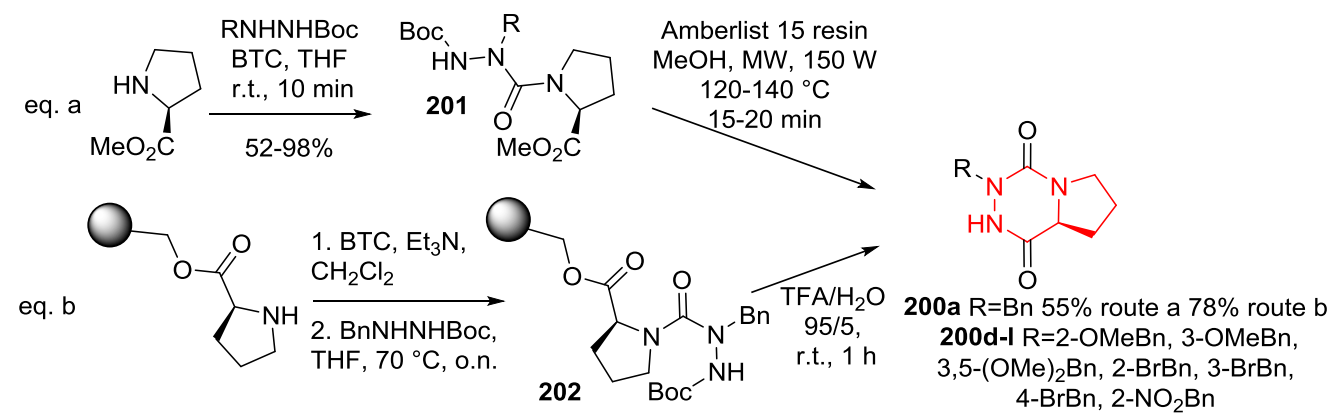

Scheme 46

Another approach to this class of molecules consists in the reaction of L-proline derivatives activated with BTC, with allyl or homoallyl $t$-butyl carbazate, and cyclization of the intermediate $\mathbf{2 0 3}$ in the presence of TFA. The pyrrolo[1,2-d][1,2,4]triazine core 204 was thus further submitted to $\mathrm{Rh}(\mathrm{I})$ catalysed cyclohydrocarbonylation, by applying a 5 bar pressure mixture of $\mathrm{H}_{2} / \mathrm{CO}$ gas in the presence of $\mathrm{Rh}(\mathrm{CO})_{2} \mathrm{acac}$ and BiPhePhos under acidic catalysis conditions (pyridinium $p$ toluenesulfonate PPTS) in THF (Scheme 47). The obtained 205 was then decorated in acidic conditions (canforsulfonic acid CSA) in $\mathrm{MeOH}$ as nucleophile to give compound $\mathbf{2 9}$ in $59 \%$ yield as cis diastereomer (96:4), as unambiguously established by X-ray analysis. [40] 

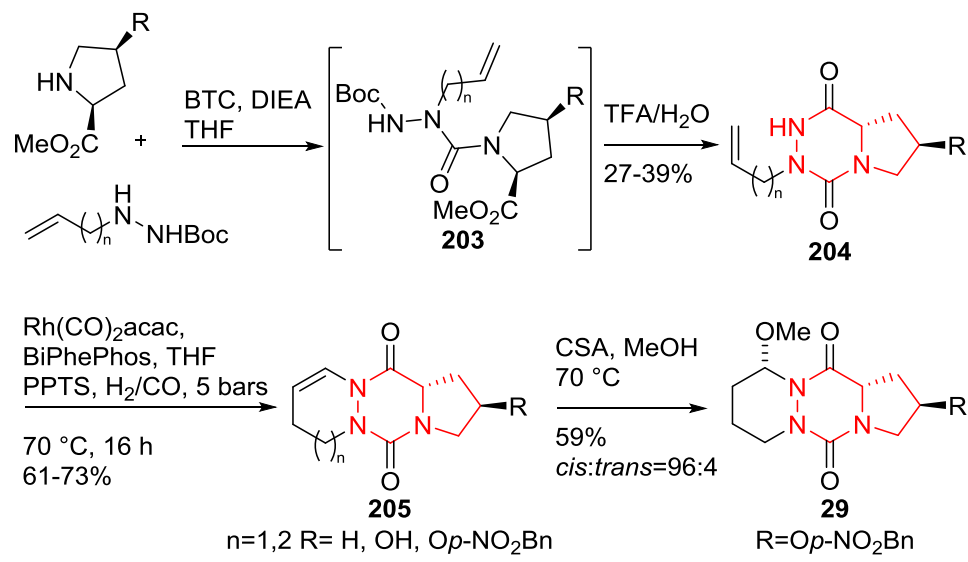

Scheme 47

Hexahydro-1H-benzo[g][1,2,4]triazino[5,4,3-cd]indolizines 209a-d were obtained via a two steps procedure involving a 1,3-dipolar cycloaddition between in situ generated azomethine ylides derived from isoquinolinium bromides 206 and phenylethylene dipolarophiles 207, followed by a heterocyclization of the cycloaddition adducts 208 upon treatment with hydrazines (Scheme 48). [94]

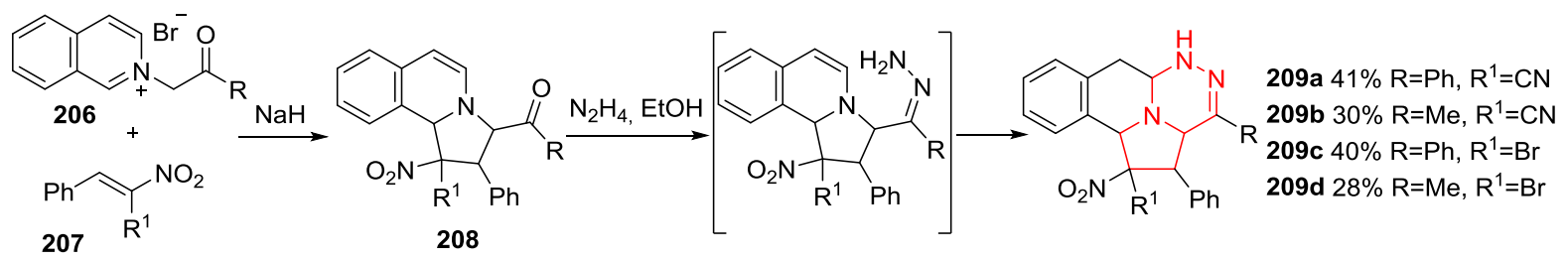

Scheme 48

The synthesis of pyrrolo[1,2-d][1,2,4]triazin-1-one $\mathbf{2 1 2}$ was achieved by addition of proline methyl ester onto the nitrile imine $\mathbf{2 1 1}$ generated in situ, from the corresponding hydrazonoyl chloride $\mathbf{2 1 0}$. In the presence of trimethylamine, the transient amidrazone ester undergoes intramolecular cyclization to deliver $34 \%$ of $\mathbf{2 1 2}$ (Scheme 49). [95]

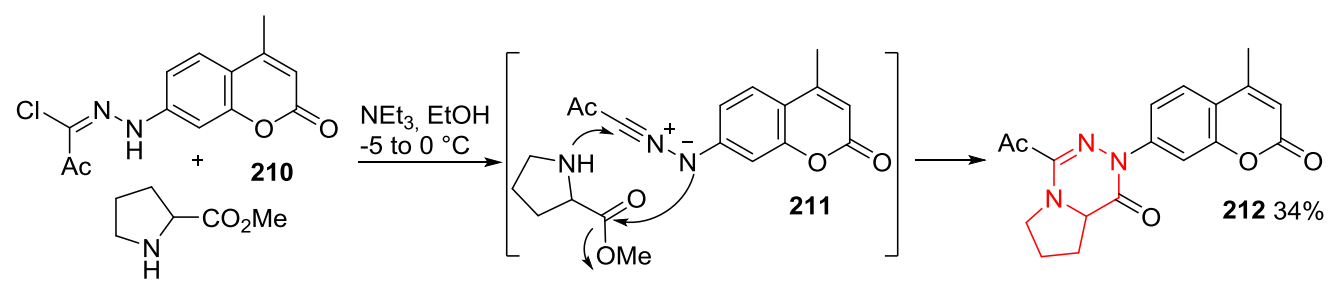

Scheme 49

By the same strategy, starting from hydrazonoyl chlorides 213, flavonoyl pyrrolo[1,2-d][1,2,4]triazin1-ones 214 were obtained (Scheme 50). [96] 


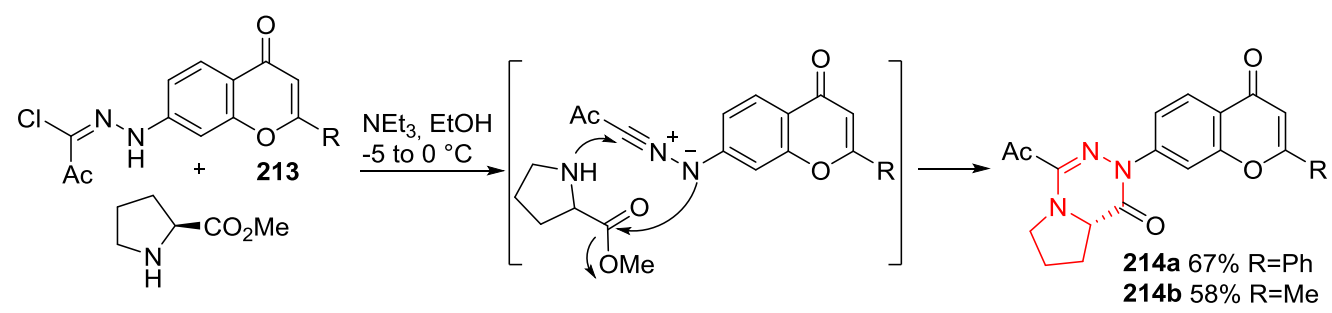

Scheme 50

Pyrrolotriazinones 216a-b can also be obtained by cyclization of $\mathrm{N}$-substituted pyrrole $\mathbf{2 1 5 a - b}$ in the presence of hydrazine in $97 \%$ and $24 \%$ yield respectively (Scheme 51 ). [97]

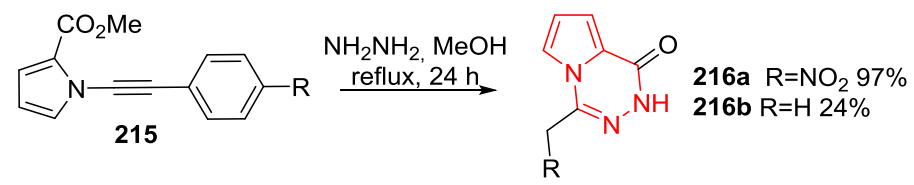

Scheme 51

The formal (3+3)-cycloaddition of azomethine imines 218 with $\mathrm{N}$-vinylpyrroles $\mathbf{2 1 7}$, catalysed by $\mathrm{AgOC}(\mathrm{O}) \mathrm{CF}_{3}$ as Lewis acid, leads to the formation of pyrazolo[1,2-a]pyrrolo[1,2-d][1,2,4]triazines 219 (Scheme 52). [24]

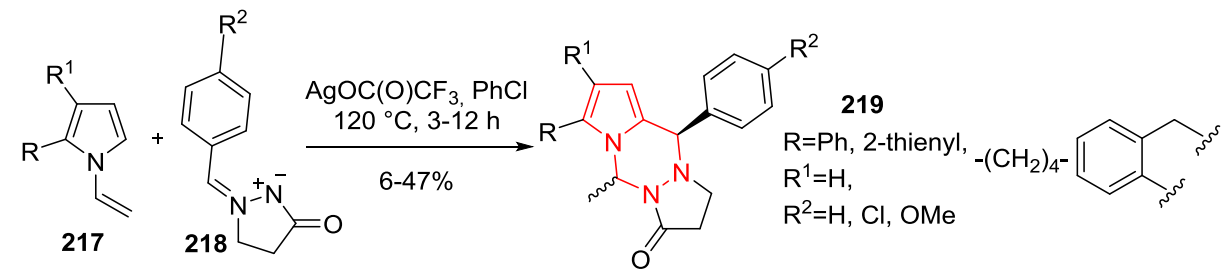

Scheme 52

\section{RING SYNTHESIS BY TRANSFORMATION OF ANOTHER RING}

Photochemical reaction of urazole 220 and 1,3-acetonedicarboxylate gave a mixture of three products, 26, 27 and 221 (Scheme 53). [37]
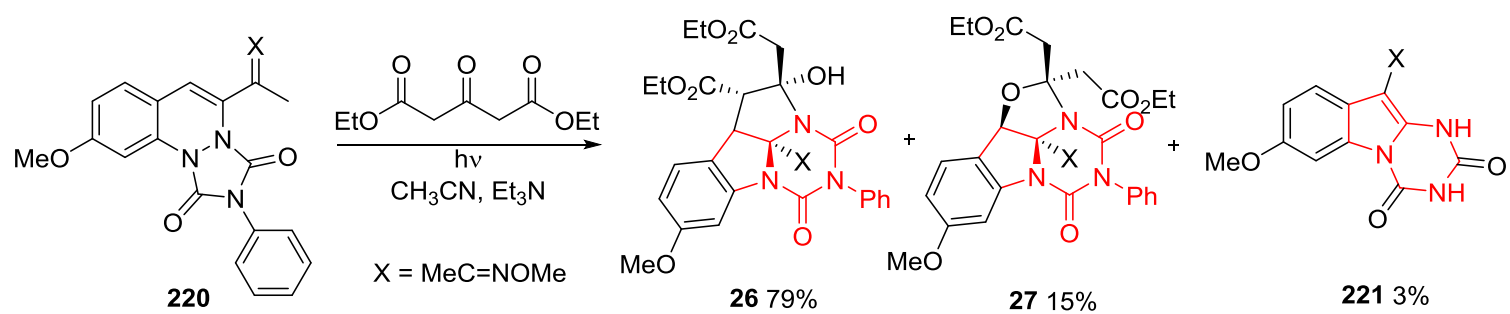

Scheme 53

\section{IMPORTANT COMPOUNDS AND APPLICATIONS}

All the compounds described in this chapter exhibited a panel of different biological activities. Among the heterocycles which fall within the scope of this chapter, undoubtedly the pyrrolo[2,1$f][1,2,4]$ triazine skeleton is a privileged fragment that constitute the core of several pharmaceutical candidates exhibiting anticancer and anti-inflammatory activities. [98] 
This scaffold makes the object of a recent reviews which explore its history and use in medicinal chemistry. [3] Remarkably the original therapeutic use of this nucleous as a C-nucleoside anti-viral agent is still and again of actuality, since recently the therapeutic efficacy of GS5734 against Ebola virus has been proved. [99]

In the period covered by this book chapter a plethora of patents have been deposited about the preparation of pyrrolo[1,2-f][1,2,4]triazines and their use as kinase inhibitors for the treatment of cancer and proliferative disorders or for treating virus infections. [100]

Another class of biologically relevant compound are molecules containing the pyrrolo[1,2d] $[1,2,4]$ triazine core, which have been evaluated for their activities as potent Rho-associated protein kinase (ROCK) inhibitors, [101] antiproliferative [102] and anticancer agents, [103] potassium ion channel [104] and acetylcholinesterase inhibitors. [105]

Some pyrrolo[1,2-b][1,2,4]triazines have been evaluated as protein kinases modulators. [106]

Pyrido[3',2':4,5]pyrrolo[1,2-c][1,2,3]benzotriazines inhibit topoisomerase 1 activity, which is unprecedented for compounds bearing the trazine core. In particular these compounds exhibit high cytotoxic activity against around 60 human tumor cell lines, with a particular efficacy against leukemia cell lines and they are also useful in treating drug-refractory patients. [76]

Finally several pyrrolo[1,2-a][1,3,5]triazines are effective as therapeutic agents for Alzheimer's and Parkinson's diseases. [107]

\section{REFERENCES}

[1] Sliskovic, D. R. in Comprehensive Heterocyclic Chemistry II, Katritzky, A. R.; Rees, C. V.; Scriven, E. F. V. Eds.; Pergamon, Oxford, 1996, vol. 8, pp. 389.

[2] Rodriguez, J.; Constantieux, T. in Comprehensive Heterocyclic Chemistry III, Katritzky, A. R.; Ramsden, C. A.; Scriven, E. F. V.; Taylor, R. J. K. Eds.; Elsevier, Amsterdam, 2008, vol. 11, pp. 629.

[3] Ott, G. R.; Favor, D. A. Bioorg. Med. Chem. Lett. 2017, 27, 4238-4246.

[4] Song, Y.; Zhan, P.; Zhang, Q.; Liu, X. Curr. Pharm. Des. 2013, 19, 1528-1548.

[5] Suneel Kumar, B. V. S.; Narasu, L.; Gundla, R.; Dayam, R.; Sarma, J. A. R. P. Curr. Pharm. Des. 2013, 19, 687-701.

[6] Cascioferro, S.; Parrino, B.; Span, V.; Carbone, A.; Montalbano, A.; Barraja, P.; Diana, P.; Cirrincione, G. Eur. J. Med. Chem. 2017, 142, 328-375.

[7]Patel, N.; Chambers, C. S.; Hemming, K. Synlett 2009, 3043-3047.

[8] Cannazza, G.; Carrozzo, M. M.; Braghiroli, D.; Parenti, C. J. Chromatogr. B 2008, 875, 192-199.

[9] Cannazza, G.; Carrozzo, M. M.; Battisti, U.; Braghiroli, D.; Parenti, C. J. Chromatogr. A 2009, 1216, 5556-5659.

[10] Carrozzo, M. M.; Cannazza, G.; Battisti, U.; Braghiroli, D.; Parenti, C. Chirality 2010, 22, 389-397.

[11] Carrozzo, M. M.; Battisti, U. M.; Cannazza, G.; Citti, C.; Parenti, C.; Troisi, L. Tetrahedron Lett. 2012, 53, 3023-3026.

[12] Carrozzo, M. M.; Battisti, U. M.; Cannazza, G.; Puia, G.; Ravazzini, F.; Falchicchio, A.; Perrone, S.; Citti, C.; Jozwiak, K.; Braghiroli, D.; Parenti, C.; Troisi, L. Bioorg. Med. Chem. 2014, 22, 4667-4676.

[13] Battisti, U. M.; Cannazza, G.; Carrozzo, M. M.; Braghiroli, D.; Parenti, C.; Rosato, F.; Troisi, L. Tetrahedron Lett. 2010, 51, 4433-4436.

[14] Lu, H.; Jiang, H.; Hu, Y.; Wojtas, L.; Zhang, X. P. Chem. Sci. 2011, 2, 2361-2366.

[15] Babij, N. R.; McKenna, G. M.; Fornwald, R. M.; Wolfe, J. P. Org. Lett. 2014, 16, 3412-3415. 
[16] Zang, Q.; Javed, S.; Porubsky, P.; Ullah, F.; Neuenswander, B.; Lushington, G. H.; Basha, F. Z.; Organ, M. G.; Hanson, P. R. ACS Comb. Sci. 2012, 14, 211-217.

[17] Ullah, F.; Zang, Q.; Javed, S.; Porubsky, P.; Neuenswander, B.; Lushington, G. H.; Hanson, P. R.; Organ, M. G. Synthesis 2012, 44, 2547-2554.

[18] Agouridas, V.; Capet, F.; Couture, A.; Deniau, E.; Grandclaudon, P. Tetrahedron: Asymmetry 2011, 22, 1441-1447.

[19] Roboredo, S.; Vicario, J. L.; Carrillo, L.; Reyes, E.; Uria, U. Synthesis 2013, 45, 2669-2678.

[20] Zhang, L.-B.; Hao, X.-Q.; Liu, Z.-J.; Zheng, X.-X.; Zhang, S.-K.; Niu, J.-L.; Song, M.-P. Angew. Chem., Int. Ed. 2015, 54, 10012-10015.

[21] Zheng, X.-X.; Du, C.; Zhao, X.-M.; Zhu, X.; Suo, J.-F.; Hao, X.-Q.; Niu, J.-L.; Song, M.-P. J. Org. Chem. 2016, 81, 4002-4011.

[22] Yadav, L.; Tiwari, M. K.; Shyamlal, B. R. K.; Mathur, M.; Swami, A. K.; Puri, S. K.; Naikade, N. K.; Chaudhary, S. RSC Adv. 2016, 6, 23718-23725.

[23] Ghinet, A.; Abuhaie, C.-M.; Homerin, G.; Marzag, H.; Dubois, J.; Lipka, E.; Rigo, B.; Daïch, A. ChemistrySelect 2017, 2, 10654-10660.

[24] Efremova, M. M.; Kostikov, R. R.; Stepakov, A. V.; Panikorovsky, T. L.; Shcherbakova, V. S.; Ivanov, A. V.; Molchanov, A. P. Tetrahedron 2017, 73, 671-680.

[25] Li, X.-N.; Zhang, Y.; Cai, X.-H.; Feng, T.; Liu, Y. P.; Li, Y.; Ren, J.; Zhu, H.-J.; Luo, X.-D. Org. Lett. 2011, 13, 5896-5899.

[26] Piemontesi, C.; Wang, Q.; Zhu, J. Angew. Chem., Int. Ed. 2016, 55, 6556-6560.

[27] Zhou, Q.; Dai, X.; Song, H.; He, H.; Wang, X.; Liu, X.-Y.; Qin, Y. Chem. Commun. 2018, 54, 95109512.

[28] Butler, D. C. Donnell; Hencken, C. P.; Iwamoto, N.; Kandasamy, P.; Lanao, A. A.; Lu, G.; Shimizu, M.; Divakaramenon, S.; Vargeese, C.; Bommineni, G. R.; et al WO 2018, 2018237194.

[29] Rausaria, S.; Kamadulski, A.; Rath, N.P.; Bryant, L.; Chen, Z.; Salvemini, D.; Neumann, W. L. J. Am. Chem. Soc. 2011, 133, 4200-4203.

[30] For very recent examples see: a) Uno, H.; Honda, T.; Kitatsuka, M.; Hiraoka, S.; Mori, S.; Takase, M.; Okujima, T.; Nakae, T. RSC Advances 2018, 8, 14072-14083; b) Mula, S.; Leclerc, N.; Leveque, P.; Retailleau, P.; Ulrich, G. J. Org. Chem. 2018, 83, 14406-14418.

[31] For very recent examples see: a) Halter, O.; Fernandez, I.; Plenio, H. Chem. - Eur. J. 2017, 23, 711-719; b) Halter, O.; Plenio, H. Chem. Commun. 2017, 53, 12461-12464.

[32] As example see: Sun, Q.; Yang, S.-H.; Wu, L.; Yang, W.-C.; Yang, G.-F. Anal. Chem. 2016, 88, 2266-2272.

[33] As example see: Wu, L.; Loudet, A.; Barhoumi, R.; Burghardt, R. C.; Burgess, K. J. Am. Chem. Soc. 2009, 131, 9156-9157.

[34] As examples see: a) Chen, N.; Zhang, W.; Chen, S.; Wu, Q.; Yu, C.; Wei, Y.; Xu, Y.; Hao, E.; Jiao, L. Org. Lett. 2017, 19, 2026-2029; b) Schellhammer, K. S.; Li, T.-Y.; Zeika, O.; Koerner, C.; Leo, K.; Ortmann, F.; Cuniberti, G. Chem. Mat. 2017, 29, 5525-5536; c) Okujima, T.; Shida, Y.; Ohara, K.; Tomimori, Y.; Nishioka, M.; Mori, S.; Nakae, T.; Uno, H. J. Porphyr. Phthalocyanines 2014, 18, 752761; d) Tomimori, Y.; Okujima, T.; Yano, T.; Mori, S.; Ono, N.; Yamada, H.; Uno, H. Tetrahedron 2011, 67, 3187-3193; e) Kubo, Y.; Minowa, Y.; Shoda, T.; Takeshita, K. Tetrahedron Lett. 2010, 51, 16001602.

[35] Leach, A. G.; Kidley, N. J. J. Chem. Inf. Model. 2011, 51, 1048-1063.

[36] Graton, G.; Le Questel, J.-Y.; Maxwell, P.; Popelier, P. L. A. J. Chem. Inf. Model. 2016, 56, 322334. 
[37] Seguchi, K.; Tanaka, S. Bull. Mukogawa Women's Univ. Nat. Sci. 2010, 58, 1-5.

[38] Seguchi, K. Bull. Mukogawa Women's Univ. Nat. Sci. 2012, 60, 11-15.

[39] Groenendaal, B.; Ruijter, E.; de Kanter F. J. J.; Lutz, M.; Spek, A. L.; Orru, R. V. A. Org. Biomol. Chem. 2008, 6, 3158-3165.

[40] Regenass, P.; Margathe, J.-F.; Mann, A.; Suffert, J.; Hibert, M.; Girard, N.; Bonnet, D. Chem. Commun. 2014, 50, 9657-9660.

[41] Xiang, H.; Chen, Y.; He, Q.; Xie, Y.; Yang, C. RSC Adv. 2013, 3, 5807-5810.

[42] Chen, J.; Liu, B.; Chen, Y.; He, Q.; Yang, C. RSC Adv. 2014, 4, 11168-11175.

[43] Mesaros, E. F.; Angeles, T. S.; Albom, M. S.; Wagner, J. C.; Aimone, L. D.; Wan, W.; Lu, L.; Huang, Z.; Olsen, M.; Kordwitz, E.; Haltiwanger, R. C.; Landis, A. J.; Cheng, M.; Ruggeri, B. A.; Ator, M. A.; Dorsey, B. D.; Ott, G. R. Bioorg. Med. Chem. Lett. 2015, 25, 1047-1052.

[44] Cho, A.; Zhang, L.; Xu, J.; Lee, R.; Butler, T.; Metobo, S.; Aktoudianakis, V.; Lew, W.; Ye, H.; Clarke, M.; Doerffler, E.; Byun, D.; Wang, T.; Babusis, D.; Carey, A. C.; German, P.; Sauer, D.; Zhong, W.; Rossi, S.; Fenaux, M.; McHutchison, J. G.; Perry, J.; Feng, J.; Ray, A. S.; Kim, C. U. J. Med. Chem. 2014, 57, 1812-1825.

[45] Siegel, D.; Hui, H. C.; Doerffler, E.; Clarke, M. O.; Chun, K.; Zhang, L.; Neville, S.; Carra, E.; Lew, W.; Ross, B.; Wang, Q.; Wolfe, L.; Jordan, R.; Soloveva, V.; Knox, J.; Perry, J.; Perron, M.; Stray, K. M.; Barauskas, O.; Feng, J. Y.; Xu, Y.; Lee, G.; Rheingold, A. L.; Ray, A. S.; Bannister, R.; Strickley, R.; Swaminathan, S.; Lee, W. A.; Bavari, S.; Cihlar, T.; Lo, M. K.; Warren, T. K.; Mackman, R. L. J. Med. Chem. 2017, 60, 1648-1661.

[46] Schroeder, G. M.; Chen, X.-T.; Williams, D. K.; Nirschl, D. S.; Cai, Z.-W.; Wei, D.; Tokarski, J. S.; An, Y.; Sack, J.; Chen, Z.; Huynh, T.; Vaccaro, W.; Poss, M.; Wautlet, B.; Gullo-Brown, J.; Kellar, K.; Manne, V.; Hunt, J. T.; Wong, T. W.; Lombardo, L. J.; Fargnoli, J.; Borzilleri, R. M. Bioorg. Med. Chem. Lett. 2008, 18, 1945-1951.

[47] Hynes, J. Jr.; Dyckman, A. J.; Lin, S.; Wrobleski, S. T.; Wu, H.; Gillooly, K. M.; Kanner, S. B.; Lonial, H.; Loo, D.; Mclntyre, K. W.; Pitt, S.; Shen, D. R.; Shuster, D. J.; Yang, X.; Zhang, R.; Behnia, K.; Zhang, H.; Marathe, P. H.; Doweyko, A. M.; Tokarski, J. T.; Sack, J. S.; Pokross, M.; Kiefer, S. E.; Newitt, J. A.; Barrish, J. C.; Dodd, J.; Schieven, G. L.; Leftheris, K. J. Med. Chem. 2018, 51, 4-16.

[48] Liu, C.; Lin, J.; Wrobleski, S. T.; Lin, S.; Hynes, J. Jr.; Wu, H.; Dyckman, A. J.; Li, T.; Wityak, J.; Gillooly, K. M.; Pitt, S.; Shen, D. R.; Zhang, R. F.; McIntyre, K. W.; Salter-Cid, L.; Shuster, D. J.; Zhang, H.; Marathe, P. H.; Doweyko, A. M.; Sack, J. S.; Kiefer, S. E.; Kish, K. F.; Newitt, J. A.; McKinnon, M.; Dodd, J. H; Barrish, J. C.; Schieven, G. L.; Leftheris, K. J. Med. Chem. 2010, 53, 6629-6639.

[49] Wrobleski, S. T.; Lin, S.; Hynes, J. Jr.; Wu, H.; Pitt, S.; Shen, D. R.; Zhang, R.; Gillooly, K. M.; Shuster, D. J.; McIntyre, K. W.; Doweyko, A. M.; Kish, K. F.; Tredup, J. A.; Ducke, G. J.; Sack, J. S.; McKinnon, M.; Dodd, J.; Barrish, J. C.; Schieven, G. L.; Leftheris, K. Bioorg. Med. Chem. Lett. 2008, 18, 2739-2744.

[50] Dyckman, A. J.; Li, T.; Pitt, S.; Zhang, R.; Shen, D. R.; Mclntyre, K. W.; Gillooly, K. M.; Shuster, D. J.; Doweyko, A. M.; Sack, J. S.; Kish, K.; Kiefer, S. A.; Newitt, J. A.; Zhang, H.; Marathe, P. H.; McKinnon, M.; Barrish, J. C.; Dodd, J. H; Schieven, G. L.; Leftheris, K. Bioorg. Med. Chem. Lett. 2011, 21, 4633-4637.

[51] Wittman, M. D.; Carboni, J. M.; Yang, Z.; Lee, F. Y.; Antman, M.; Attar, R.; Balimane, P.; Chang, C.; Chen, C.; Discenza, L.; Frennesson, D.; Gottardis, M. M.; Greer, A.; Hurlburt, W.; Johnson, W.; Langley, D. R.; Li, A.; Li, J.; Liu, P.; Mastalerz, H.; Mathur, A.; Menard, K.; Patel, K.; Sack, J.; Sang, X.; Saulnier, M.; Smith, D.; Stefanski, K.; Trainor, G.; Velaparthi, U.; Zhang, G.; Zimmermann, K.; Vyas, D. M. J. Med. Chem. 2009, 52, 7360-7363. 
[52] Sapognaro, A. J.; Wittman, M. D.; Carboni, J. M.; Chang, C.; Greer, A. F.; Hurlburt, W. W.; Sack, J. S.; Vyas, D. M. Bioorg. Med. Chem. Lett. 2010, 20, 5027-5030.

[53] Wang, L.; Stanley, M.; Boggs, J. W.; Crawford, T. D.; Bravo, B. J.; Giannetti, A. M.; Harris, S. F.; Magnuson, S. R.; Nonomiya, J.; Schmidt, S.; Wu, P.; Ye, W.; Gould, S. E.; Murray, L. J.; Ndubaku, C. O.; Chen, H. Bioorg. Med. Chem. Lett. 2014, 24, 4546-4552.

[54] Ding, Z.-G.; Zhao, J.-Y.; Yang, P.-W.; Li, M.-G.; Huang, R.; Cui, X.-L.; Wen, M.-L. Magn. Res. Chem. 2009, 47, 366-370.

[55] Zemanová, I.; Gašparová, R. Nova Biotechnol. Chim. 2017, 16, 147-151.

[56] Lu, C.; Dong, M.; Zhu, H. Y. J. Org. Chem. 2017, 82, 9229-9234.

[57] Zemanová, I.; Gašparová, R.; Boháč, A.; Maliar, T.; Kraic, F.; Addová, G. Arkivoc 2017, v, 204-215.

[58] Ott, G. R.; Wells, G. J.; Thieu, V. T.; Quail, M. R.; Lisko, J. G.; Mesaros, E. F.; Gingrich, D. E.; Ghose, A. K.; Wan, W.; Lu, L.; Cheng, M.; Albom, M. S.; Angeles, T. S.; Huang, Z.; Aimone, L. D.; Ator, M. A.; Ruggeri, B. A.; Dorsey, B. D. J. Med. Chem. 2011, 54, 6328-6341.

[59] Xin, M.; Zhang, L.; Tang, F.; Tu, C.; Wen, J.; Zhao, X.; Liu, Z.; Cheng, L.; Shen, H. Bioorg. Med. Chem. 2014, 22, 1429-1440.

[60] Mesaros, E. F.; Thieu, T. V.; Wells, G. J.; Zificsak, C. A.; Wagner, J. C.; Breslin, H. J.; Tripathy, R.; Diebold, J. L.; McHugh, R. J.; Wohler, A. T.; Quail, M. R.; Wan, W.; Lu, L.; Huang, Z.; Albom, M. S.; Angeles, T. S.; Wells-Knecht, K. J.; Aimone, L. D.; Cheng, M.; Ator, M. A.; Ott, G. R.; Dorsey, B. D. J. Med. Chem. 2012, 55, 115-125.

[61] Cai, Z-W.; Wei, D.; Borzilleri, R. M.; Qian, L.; Kamath, A.; Mortillo, S.; Wautlet, B.; Henley, B. J.; Jeyaseelan, R.; Tokarski, J. S.; Hunt, J. T.; Bhide, R. S.; Fargnoli, J.; Lombardo, L. J. Bioorg. Med. Chem. Lett. 2018, 18, 1354-1358.

[62] Wang, J.; Wang, X.; Chen, Y.; Chen, S.; Chen, G.; Tong, L.; Meng, L.; Xie, Y.; Ding, J.; Yang, C., Bioorg. Med. Chem. Lett. 2012, 22, 339-342.

[63] Gavai, A. V.; Fink, B. E.; Fairfax, D. J.; Martin, G. S.; Rossiter, L. M.; Holst, C. L.; Kim, S.-H.; Leavitt, K. J.; Mastalerz, H.; Han, W. C.; Norris, D.; Goyal, B.; Swaminathan, S.; Patel, B.; Mathur, A.; Vyas, D. M.; Tokarski, J. S.; Yu, C.; Oppenheimer, S.; Zhang, H.; Marathe, P.; Fargnoli, J.; Lee, F. Y.; Wong, T. W.; Vite G. D. J. Med. Chem. 2009, 52, 6527-6530.

[64] Shi, W.; Qiang, H.; Huang, D.; Bi, X.; Huang, W.; Qian, H. Eur. J. Med. Chem. 2018, 158, 814-831.

[65] Thieu, T.; Sclafani, J. A.; Levy, D. V.; McLean, A.; Breslin, H. J.; Ott, G. R.; Bakale, R. P.; Dorsey, B. D. Org. Lett. 2011, 13, 4202-4207.

[66] Kim, T.; Son, W. S.; Morshed, M. N.; Londhe, A. M.; Jung, S. Y.; Park, J.-H.; Park, W.-K.; Lim, S. M.; Park, K. D.; Cho, S. J.; Jeong, K.-S.; Lee, J.; Pae, A. N. Eur. J. Med. Chem. 2017, 141, 240-256.

[67] Zemanová, I.; Gašparová, R.; Kraic, F.; Kružlicová, D.; Maliar, T.; Boháč, A.; Addová, G. Arkivoc 2017, iv, 184-193.

[68] Lim, J.; Altman, M. D.; Baker, J.; Brubaker, J. D.; Chen, H.; Chen, Y.; Kleinschek, M. A.; Li, C.; Liu, D.; Maclean, J. K. F.; Mulrooney, E. F.; Presland, J.; Rakhilina, L.; Smith, G. F.; Yang, R. Bioorg. Med. Chem. Lett. 2015, 25, 5384-5388.

[69] Fink, B. E.; Norris, D.; Mastalerz, H.; Chen, P.; Goyal, B.; Zhao, Y.; Kim, S.-H.; Vite, G. D.; Lee, F. Y.; Zhang, H.; Oppenheimer, S.; Tokarski, J. S.; Wong, T. W.; Gavai, A. V. Bioorg. Med. Chem. Lett. 2011, 21, 781-785.

[70] Wang, M.; Gao, M.; Zheng, Q.-H. Bioorg. Med. Chem. Lett. 2014, 24, 3700-3705.

[71] a) Cho, A.; Saunders, O. L.; Butler, T.; Zhang, L.; Xu, J.; Vela, J. E.; Feng, J. Y.; Ray, A. S.; Kim, C. U. Bioorg. Med. Chem. Lett. 2012, 22, 2705-2707; b) Cho, A.; Zhang, L.; Xu, J.; Babusis, D.; Butler, T.; Lee, R.; Saunders, O. L.; Wang, T.; Parrish, J.; Perry, J.; Feng, J. Y.; Ray, A. S.; Kim, C. U. Bioorg. Med. 
Chem. Lett. 2012, 22, 4127-4132; c) Draffan, A. G.; Frey, B.; Fraser, B. H.; Pool, B.; Gannon, C.; Tyndall, E. M.; Cianci, J.; Harding, M.; Lilly, M.; Hufton, R.; Halim, R.; Jahangiri, S.; Bond, S.; Jeynes, T. P.; Nguyen, V. T. T.; Wirth, V.; Luttick, A.; Tilmanis, D.; Pryor, M.; Porter, K.; Morton, C. J.; Lin, B.; Duan, J.; Bethell, R. C.; Kukolj, G.; Simoneau, B.; Tucker, S. P. Bioorg. Med. Chem. Lett. 2014, 24, 4984-4988; d) Draffan, A. G.; Frey, B.; Pool, B.; Gannon, C.; Tyndall, E. M.; Lilly, M.; Francom, P.; Hufton, R.; Halim, R.; Jahangiri, S.; Bond, S.; Nguyen, V. T. T.; Jeynes, T. P.; Wirth, V.; Luttick, A.; Tilmanis, D.; Thomas, J. D.; Pryor, M.; Porter, K.; Morton, C. J.; Lin, B.; Duan, J.; Kukolj, G.; Simoneau, B.; McKercher, G.; Lagacé, L.; Amad, M.; Bethell, R. C.; Tucker, S. P. ACS Med. Chem. Lett. 2014, 5, 679-684; e) Tyndall, E. M.; Draffan, A. G.; Frey, B.; Pool, B.; Halim, R.; Jahangiri, S.; Bond, S.; Wirth, V.; Luttick, A.; Tilmanis, D.; Thomas, J.; Porter, K.; Tucker, S. P. Bioorg. Med. Chem. Lett. 2015, 25, 869873.

[72] Li, Q.; Lescrinier, E.; Groaz, E.; Persoons, L.; Daelemans, D.; Herdewijn, P.; De Jonghe, S. ChemMedChem 2018, 13, 97-104.

[73] Astakhina, V.; Voievudskyi, M.; Kharchenko, O.; Novikov, V.; Komarovska-Porohnyavets, E.; Petukhova, O. J. Heterocyclic Chem. 2016, 53, 421-428.

[74] Zaky, H. T.; Mohamed, M. I.; Kandile, N. G. Arabian J. Chem. 2014, 7, 630-638.

[75] Pitt, W. R.; Parry, D. M.; Perry, B. G.; Groom, C. R. J. Med. Chem. 2009, 52, 2952-2963.

[76] Parrino, B.; Carbone, A.; Muscarella, M.; Spanò, V.; Montalbano, A.; Barraja, P.; Salvador, A.; Vedaldi, D.; Cirrincione, G.; Diana, P. J. Med. Chem. 2014, 57, 9495-9511.

[77] Pang, X.; Zhao, L.; Zhou, D.; He, P. Y.; An, Z.; Ni, J. X.; Yan, R. Org. Biomol. Chem. 2017, 15, 63186322.

[78] Zheng, B.; Conlon, D. A.; Corbett, R. M.; Chau, M.; Hsieh, D.-M., Yeboah, A.; Hsieh, D.; Müslehiddinoğlu, J.; Gallagher, W. P.; Simon, J. N.; Burt, J. Org. Process Res. Dev. 2012, 16, 18461853.

[79] Saito, T.; Obitsu, T.; Kohno, H.; Sugimoto, I.; Matsushita, T.; Nishiyama, T.; Hirota, T.; Takeda, H.; Matsumura, N.; Ueno, S.; Kishi, A.; Kagamiishi, Y.; Nakai, H.; Takaoka, Y. Bioorg. Med. Chem. 2012, 20, 1122-1138.

[80] Chen, Y.; Xiang, H.; Tan, C.; Xie, Y.; Yang, C. Tetrahedron 2013, 69, 2714-2719.

[81] Bel'skaya, N. P.; Koksharov, A. V.; Deryabina, T. G.; Bakulev, V. A. Chemistry of Heterocyclic Compounds, New York, NY, United States, 2010, 46, pp. 1156-1157.

[82] Xu, H.; Fan, L.-L. Eur. J. Med. Chem. 2011, 46, 364-369.

[83] Abou-Elmagd, W. S. I.; Hashem, A. I. J. Heterocyclic Chem. 2012, 49, 947-950.

[84] Arief, M. M. H.; Ahmed, M. H. M.; Said, A. A.; Selim, N. M. M. Int. J Basic Appl. Sci. 2013, 2, 153159.

[85] Chakraborty, A.; Jana, S.; Kibriya, G.; Dey, A.; Hajra, A. RSC Adv. 2016, 6, 34146-34152.

[86] El-Shaieb, K. M.; Ameen, M. A.; Abdel-latif, F. F.; Mohamed, A. H. Z. Naturforsch 2013, 68b, 905912.

[87] Tseitler, T. A.; Zyryanov, G. V.; Kopchuk, D. S.; Kovalev, I. S.; Rusinov, V. L.; Chupakhin, O. N. Russ. J. Org. Chem. 2014, 50, 783-785.

[88] Kudelko, A.; Zieliński W.; Ejsmont, K. Tetrahedron 2011, 67, 7838-7845.

[89] Boisse, T.; Gavara, L.; Gautret P.; Baldeyrou, B.; Lansiaux, A.; Goossens, J.-F.; Hénichart, J.-P.; Rigo, B. Tetrahedron Lett. 2011, 52, 1592-1596.

[90] Soares M. I. L.; Pinho e Melo, T. M. V. D. Tetrahedron Lett. 2008, 49, 4889-4893.

[91] Soares M. I. L.; Pinho e Melo, T. M. V. D. Curr. Microw. Chem. 2014, 1, 22-32.

[92] Bourguet, C. B.; Proulx, C.; Klocek, S.; Sabatino, D.; Lubell, W. D. J. Pept. Sci. 2010, 16, 284-296. 
[93] Bonnet, D.; Margathe, J.-F.; Radford, S.; Pflimlin, E.; Riché, S.; Doman, P.; Hibert, M.; Ganesan, A. ACS Comb. Sci. 2012, 14, 323-334.

[94] Nosachev, S. B.; Del'netskaya, K. A.; Solov'ev, N. A.; Tyrkov, A. G. Russ. J. Org. Chem. 2010, 46, 1427-1429

[95] Mustafa, M. S.; El-Abadelah, M. M.; Mubarak, M. S.; Chibueze, I.; Shao, D.; Agu, R. U. Int. J. Chem. 2011, 3, 89-113.

[96] Abu-Aisheh, M. N.; Mustafa, M. S.; Mubarak, M. S.; El-Abadelah, M. M.; Voelter, W. Lett. Org. Chem. 2012, 9, 465-473.

[97] Yenice, I.; Basceken, S.; Balci, M. Beilstein J. Org. Chem. 2017, 13, 825-834.

[98] a) Liu, G.; Abraham, S.; Tran, L.; Vickers, T. D.; Xu, S.; Hadd, M. J.; Quiambao, S.; Holladay, M. W.; Hua, H.; Ford Pulido, J. M.; Gunawardane, R. N.; Davis, M. I.; Eichelberger, S. R.; Apuy, J. L.; Gitnick, D.; Gardner, M. F.; James, J.; Breider, M. A.; Belli, B.; Armstrong, R. C.; Treiber, D. K. J. Med. Chem. 2012, 55, 3250-3260; b) Wong, T. W.; Lee, F. Y.; Emanuel, S.; Fairchild, C.; Fargnoli, J.; Fink, B.; Gavai, A.; Hammell, A.; Henley, B.; Hilt, C.; Hunt, J. T.; Krishnan, B.; Kukral, D.; Lewin, A.; Malone, H.; Norris, D.; Oppenheimer, S.; Vite, G.; Yu, C. Clin. Cancer Res. 2011, 17, 4031-4041; c) Gavai, A. V.; Fink, B. E.; Fairfax, D. J.; Martin, G. S.; Rossiter, L. M.; Holst, C. L.; Kim, S.-H.; Leavitt, K. J.; Mastalerz, H.; Han, W.-C.; Norris, D.; Goyal, B.; Swaminathan, S.; Patel, B.; Mathur, A.; Vyas, D. M.; Tokarski, J. S.; Yu, C.; Oppenheimer, S.; Zhang, H.; Marathe, P.; Fargnoli, J.; Lee, F. Y.; Wong, T. W.; Vite, G. D. J. Med. Chem. 2009, 52, 6527-6530; d) Dinchuk, J. E.; Cao, C.; Huang, F.; Reeves, K. A.; Wang, J.; Myers, F.; Cantor, G. H.; Zhou, X.; Attar, R. M.; Gottardis, M.; Carboni, J. M. Endocrinology 2010, 151, 41234132.

[99] Warren, T. K.; Jordan, R.; Lo, M. K.; Ray, A. S.; Mackman, R. L.; Soloveva, V.; Siegel, D.; Perron, M.; Bannister, R.; Hui, H. C.; Larson, N.; Strickley, R.; Wells, J.; Stuthman, K. S.; Van Tongeren, S. A.; Garza, N. L.; Donnelly, G.; Shurtleff, A. C.; Retterer, C. J.; Gharaibeh, D.; Zamani, R.; Kenny, T.; Eaton, B. P.; Grimes, E.; Welch, L. S.; Gomba, L.; Wilhelmsen, C. L.; Nichols, D. K.; Nuss, J. E.; Nagle, E. R.; Kugelman, J. R.; Palacios, G.; Doerffler, E.; Neville, S.; Carra, E.; Clarke, M. O.; Zhang, L.; Lew, W.; Ross, B.; Wang, Q.; Chun, K.; Wolfe, L.; Babusis, D.; Park, Y.; Stray, K. M.; Trancheva, I.; Feng, J. Y.; Barauskas, O.; Xu, Y.; Wong, P.; Braun, M. R.; Flint, M.; McMullan, L. K.; Chen, S.-S.; Fearns, R.; Swaminathan, S.; Mayers, D. L.; Spiropoulou, C. F.; Lee, W. A.; Nichol, S. T.; Cihlar, T.; Bavari, S. Nature 2016, 531, 381-385.

[100] a) Bryan, M. C.; Drobnick, J.; Gobbi, A.; Katsumoto, T.; Rajapaksa, N.; Kiefer, J. R. WO 2018, 2018234343; b) Harikrishnan, L. S.; Fink, B. E.; Borzilleri, R. M.; Tonukunuru, G.; Rahaman, H.; Warrier, J. S.; Seshadri, B. WO 2017, 2017015425; c) Yang, C.; Meng, L.; Chen, Y.; Wang, X.; Tan, C.; Li, J.; Ding, J.; Chen, Y. US 2017, 20170000800; d) Yamamoto, S.; Tokura, H.; Kurono, M.; Nomura, Y.; Hotta, S. WO 2016, 2016208595; e) Lim, J.; Altman, M. D.; Brubaker, J. D.; Gibeau, C. R. WO 2016, 2016144848; f) Dzierba, C. D.; Dasgupta, B.; Macor, J. E.; Bronson, J. J.; Rajamani, R.; Karageorge, G. N., WO 2015, 2015054358; g) Clarke, M.; O'Neil H.; Doerffler, E.; Mackman, R. L.; Siegel, D. WO 2015, 2015069939; h) Erra Sola, M.; Taltavull Moll, J. WO 2014, 2014124757; i) An, X.; Bie, P.; Yang, W.; Liu, J. WO 2014, 2014082230; j) Yang, C.; Meng, L.; Chen, Y.; Wang, X.; Tan, C.; Li, J.; Ding, J.; Chen, Y. WO 2013, 2013177983; k) Wu, X.; Yang, M.; Shu, Q.; Zhu, C. WO 2013, 2013178021; I) Magnuson, S.; Wickens, P.; Zhang, Z.; Qi, N.; Ma, X. US 2012, 8138336; m) Babu, Y. S.; Kotian, P. L.; Wu, M. WO 2011, 2011150356; n) Abraham, S.; Bhagwat, S. S.; Hadd, M. J.; Holladay, M. W.; Liu, G.; Milanov, Z. V.; Patel, H. K.; Setti, E.; Sindac, J.A. WO 2011, 2011088045; o) Allen, D. R.; Buerli, R.; Haughan, A. F.; Matteucci, M.; Owens, A. P.; Raphy, G.; Sharpe, A. WO 2011, 2011058109; p) Moriarty, K. J.; Konteatis, Z.; Moffett, K.; Lee, Y.; Chao, W. WO 2010, 2010126960 (2010); q) Breslin, H. J.; 
Chatterjee, S.; Diebold, J. L.; Dorsey, B. D.; Dunn, D.; Gingrich, D. E.; Hostetler, G. A.; Hudkins, R. L.; Hunter, R.; Josef, K.; et al WO 2010, 2010071885; r) Magnuson, S.; Wickens, P.; Zhang, Z.; Qi, N.; Ma, X. WO 2009, 2009042543; s) Fink, B. E.; Chen, P. WO 2008, 2008057994.

[101] a) Hu, Z.; Wang, C.; Quan, M. L.; Glunz, P. W. WO 2018, 2018009622; b) Ladziata, V.; Glunz, P. W.; Hu, Z.; Wang, Y. US 2016, 20160016914; c) Curtin, M. L.; Sorensen, B. K.; Heyman, H. R.; Clark, R. F.; Woller, K. R.; Shah, O. J.; Michaelides, M.; Tse, C.; Vasudevan, A.; Mack, H.; et al US 2012, 20120122842.

[102] Strum, J. C.; Jung, D. WO 2018, 2018005860.

[103] Jeon, S. D.; Hwang, S. W.; Park, S. Y.; Kang, K. R.; Bin, H. R.; Ji, Y. H.; Yoon, S. K.; Kim, S. H.; Kim, N. D.; Lee, S. W.; et al WO 2017, 2017034294.

[104] a) Finlay, H.; Adisechan, A. K.; Gunaga, P.; Lloyd, J.; Pothukanuri, S. US 2016, 20160009719; b)

Finlay, H.; Adisechan, A. K.; Gunaga, P.; Lloyd, J.; Pothukanuri, S. WO 2014, 2014143606.

[105] Järvinen, P. P.; Fallarero, A.; Gupta, S.; Mohan, G. C.; Hatakka, A. I.; Vuorela, P. M. Comb. Chem. High Throughput Screen. 2010, 13, 278-284.

[106] Cui, J. J.; LI, Y.; Rogers, E. W. Z. D. WO 2015, 2015112806.

[107] a) Skerlj, R. T.; Bourque, E. M. J.; Lansbury, P. T. WO 2017, 2017192929; b) Nakazato, A.; Okubo, T.; Nozawa, D.; Tamita, T.; Kennis, L. E. J. US 2012, 8106194.

\section{Bibliographical Sketch}

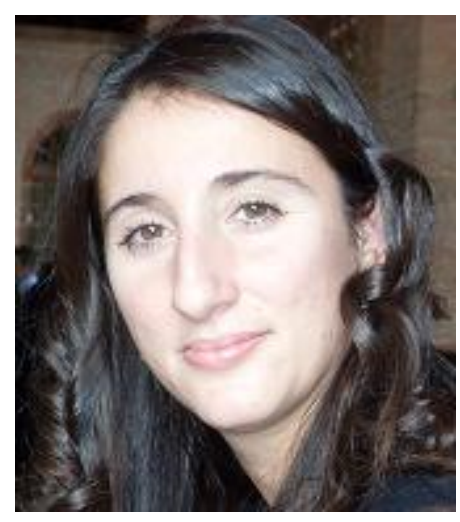

Dr. Claudia Lalli received her PhD degree in 2009 from the University of Florence (Italy) under the supervision of Pr. A. Guarna, on the diversity-oriented synthesis of peptidomimetics. She joined the group Pr. J. Zhu at the Institut de Chimie des Substances Naturelles (ICSN) as a post-doc fellow on the development of new multicomponent reactions. In 2011 she has obtained a second postdoctoral position in the group of Dr. G. Masson (ICSN) working on the development of new enantioselective transformations using chiral phosphoric acid catalysts. In 2012, she was appointed as Chargé de Recherche at the CNRS at the University of Rennes. Her research interests are focused around the development of new organocatalytic enantioselective reactions and their application in the synthesis of biologically active compounds. 